\title{
3 Research Suare

\section{Unveiling the Past, Current and Future of Global Sustainable Livelihoods Research by Visual and Quantitative Analysis}

\section{Tong Li}

University of Chinese Academy of Sciences

Lizhen Cui

University of Chinese Academy of Sciences

Ranjay K. Singh

Central Agricultural University

\section{Francesco Fava}

Università degli Studi di Milano

\section{Zhihong Xu}

Griffith University

\section{Shalander Kumar}

7. International Crop Research Institute for the Semi-Arid Tropics

\section{Xiufang Song}

National Science Library, Chinese Academy of Sciences,

\section{Li Tang}

University of Chinese Academy of Sciences

\section{Yanfen Wang}

University of Chinese Academy of Sciences

\section{Yanbin Hao}

University of Chinese Academy of Sciences

Xiaoyong Cui ( $\nabla$ cuixy@ucas.ac.cn )

University of Chinese Academy of Sciences

\section{Article}

Keywords:

Posted Date: July 21st, 2021

DOI: https://doi.org/10.21203/rs.3.rs-735256/v1 
License: (c) (i) This work is licensed under a Creative Commons Attribution 4.0 International License. Read Full License 


\section{Abstract}

Sustainable Livelihoods (SLs) is now a high-priority field in global environmental change research, becoming one of the key research paradigms in sustainability science increasingly and an important component of the Sustainable Development Goals. A Scientometrics analysis based on Science Citation Index-Expanded was performed to understand the research trends and areas in SLs studies. A total of 6441 papers related to SLs studies and 265, 759 references published from 1991 to 2020 were selected as the research objects. Using advanced quantitative analysis tools such as CiteSpace and VOSviewer, we quantify and visualize the characteristics and evolution of the literature in the field of SLs research, to clarify the historical research characteristics, knowledge base, and future research trends. The results show that the annual number of documents increased exponentially since 1991. Ecological sciences and ecology were the most popular Web of Science research areas. The institution with the greatest research documents and most citations was the CGIAR. The most influential journal is Word Development. Singh

R.K., Shackleton C.M., was the most productive author. Six clusters of research areas were determined by keyword co-occurrence analysis. The results of the evolution of research hotspots show that the four tags currently still active. We also detected 11 directions of SLs research studies based on the keywords' score relevance, which has allowed the iden-tification of future lines of research with more importance. These results can help related researchers better understand the past current and future of SLs research studies, which is significant for achieving livelihoods sustainability.

\section{Introduction}

Sustainable Livelihoods (SLs) are activities that restore, enhance, and maintain long-term viability, assets, and engagement when people's lives are threatened and stressed, without destroying resources and providing an opportunity for future generations (Chambers, 1991; Scoones, 2009). Since its inception, the concept has attracted widespread international attention, providing a new perspective for studying the sustainable development of rural economy, society, and environment. Especially in providing contemporary perspectives on poverty eradication. This theory attributes the root cause of poverty to the lack of intrinsic motivation of the poor themselves. The development of SLs can be traced back to the earliest studies on poverty by Sen (Reutlinger, 1984; Sen, 1981), Chambers (Chambers, 1991), and others in the 1980s and early 1990s. In addition to focusing on income poverty in the traditional sense, they also placed special emphasis on developmental capability poverty (i.e., lack of ability to choose and accomplish basic livelihood activities, poverty of loss of good development opportunities, etc.), which is the basic prototype of the sustainable livelihood research framework. With the convening of the United Nations Conference on Environment and Development, the Brundtland Commission first explicitly introduced the concept of sustainable development and sustainable livelihoods in the form of an official document in 1987 in "our common future," which attracted great attention (Borowy, 2013; Martha G. Roberts, 2003).In 1992, the United Nations Conference on Environment and Development introduced the concept of sustainable livelihoods provided by Chambers and Conway into the action agenda (Chambers, 1991), advocating stable livelihoods as the main goal of poverty eradication. At that point, the concept 
became the mainstream concept for future research in the field. Subsequent conferences such as the International Conference on Population and Development in 1994, the World Summit for Social Development(WSSD) in 1995 (Borowy, 2013), and the World Conference on Women in 1995 further emphasized the importance of sustainable livelihoods for poverty reduction policies and sustainable human development. Subsequently, the United Nations Millennium Declaration, adopted in 2000, explicitly set the goal of halving extreme poverty by 2015 from the 1990 level for the first time of an international convention, an international document with development goals focused on vulnerable groups and the achievement of sustainable livelihoods. 2015 saw the United Nations again adopt the 2030 Agenda for Sustainable Development (Editorial, 2018), which again emphasizes the achievement of sustainable livelihoods as the core of global sustainable development goals 2030 (SDG 2030 contains 17 goals, 169 sub-goals, and 232 targets, of which more than 160 are directly or indirectly related to sustainable livelihoods) (Editorial, 2018; Peng et al., 2020; Zhilin et al., 2020), fully reflecting the importance of sustainable livelihoods in global sustainable development, and the same time, the concept of sustainable development provides a clearer and more integrated approach to addressing global poverty, providing target guidance for achieving global sustainable livelihoods.

In recent years, research interest in sustainable livelihoods approaches (SLA) that a critical tool for SLs has increased day by day and has received widespread attention (Hahn et al., 2009). The basic concept of the SLA originated from the deepening of the understanding of poverty attributes in the 1980s and early 1990s. Scientists are increasingly concerned about the poverty of progress ability, that is, the lack of ability to choose and complete basic livelihood activities. Many development agencies have researched sustainable livelihoods in both empirical and theoretical frameworks. At present, there are a variety of SLA analysis frameworks coexisting. There are three currently accepted mainstream approaches. These are the Sustainable Livelihoods Approach established by The UK's Department for International Development (DFID) in 2000 (the institute has changed the name, called The Foreign, Commonwealth and Development Office, FCDO), the Cooperative for American Remittances to Everywhere (CARE) in the US, and the United Nations Development Programme (UNDP) Sustainable Livelihoods Approach. The UK's Department for International Development (DFID) Sustainable Livelihoods Approach was established in 2000, the Cooperative for American Remittances to Everywhere (CARE) Farmers' Livelihood Security Framework, and the United Nations Development Programme (UNDP) Sustainable Livelihoods Approach. Other organizations and institutions such as the Food and Agriculture Organization and the World Bank have developed their different frameworks for sustainable livelihoods analysis, both independently and collaboratively, and some researchers such as Scoones, Bebbington, Ellis, and others have developed frameworks for sustainable livelihoods analysis. Scoones argues that research focusing on livelihood assets and their components is an important avenue for sustainable livelihoods and related research and that there should be a broad academic exchange with the prevailing economic thinking of the time (Scoones, 1998). The areas of focus vary. Among them, the SLA framework established by DFID (Fig. 1), which has been most widely adopted and implemented, has become a classic paradigm for an academic analysis of sustainable livelihoods research, providing a systematic way of thinking for its normative analysis. Among the various frameworks, the sustainable livelihoods framework (SLF) that 
proposed by the United of the Kingdom Department for International Development (DFID), which is excellent and has been widely used by many organizations and researchers (Carney, 2002; DFID, 1999; Knutsson, 2006; Morse et al., 2013; Serrat, 2017). Compared to traditional livelihood studies, SLA is considered an improved and well-structured approach to gain a better understanding of poverty at the micro-level, as it influences both policy and the process of institutional change. In the framework, there are five main components, including a vulnerability context, livelihood assets, transforming structure and processes, livelihood strategies, and outcomes (Carney, 2002; DFID, 1999). The vulnerability context refers to the variable external environment which is out of an individual's control. Specifically, it is including shock, trends, and seasonality. Livelihood assets include human $(H)$, physical $(P)$, social $(S)$, financial $(F)$, and natural $(\mathrm{N})$ assets. People's decisions and the activities that people endeavor to achieve their goals are described as livelihood strategies (Zhao et al., 2020; Zhao et al., 2019). Simply put, this framework views poor farmers as surviving or earning a living in a context of vulnerability, where they have certain livelihood assets, and their access to livelihood assets is determined by the collective, institutional, and organizational environment. At the same time, this context also influences the livelihood strategies (the way assets are allocated and utilized) of farmers to meet their livelihood objectives.

The SLA framework established by DFID has played a leading role in subsequent research on sustainable livelihoods, and many researchers and international institutions have conducted a large number of qualitative or quantitative studies based on this framework from different perspectives, mainly focusing on the following areas: livelihoods and poverty, livelihood diversity, livelihood vulnerability, land use and farm livelihoods, energy consumption and rural livelihoods, and ecological construction and livelihoods. Meanwhile,Siegel et al. proposed a conceptual framework for assessing vulnerability based on livelihood assets based on SLF and pointed out that the framework can be used at different levels (such as individuals, families, villages, small watersheds, regions, or countries) (Siegel et al., 2005). This study provides new research ideas to broaden the study of sustainable livelihoods by different research scales. Several scholars have conducted extensive research on many aspects of farmers' livelihoods using sustainable livelihood analysis methods, such as livelihood diversity (Smith et al., 2001), livelihood Vulnerability (Hahn et al., 2009), livelihood Security (Singh and Hiremath, 2010), farmers' livelihoods, and poverty eradication (Ellis and Bahiigwa, 2003),energy consumption, and farmers' livelihoods (Cherni and Hill, 2009), land Use and Farmers' Livelihoods (Soini, 2005). Specifically, for example, Ferrol-Schulte et al. provide a systematic review of the application of sustainable livelihood analysis methods to tropical coastal and marine socio-ecological systems (Ferrol-Schulte et al., 2013). Cherni et al. studied the relationship between renewable energy and farm household livelihoods using sustainable livelihoods approach in a remote rural community in Cuba and found that an effective combination of small-scale renewable energy technologies and government sustainable development policies is the best option for promoting renewable energy services and can significantly improve the sustainability of farm household livelihoods (Cherni and Hill, 2009). Fan et al. also conducted a series of studies on sustainable livelihoods in high-altitude areas of Tibet and identified the barrier factors and coping strategies for sustainable livelihoods in the context of vulnerability (Zhao et al., 2020; Zhao et al., 2019). Other scholars have designed a comprehensive evaluation index for sustainable livelihood security in developing countries 
from a comprehensive perspective. Singh et al. (Singh and Hiremath, 2010) proposed a sustainable livelihood security index by considering three aspects: ecological security, economic efficiency, and social equity, and conducted an empirical study in eastern India, proving that this approach can effectively balance the common concerns of economists, environmentalists, and egalitarians, and can provide a reference for achieving sustainable development (You and Zhang, 2017). Sneddon explains and summarizes the evolution and development of theories related to sustainability to bring different researchers' conceptual and practical perspectives of different researchers' to the forefront of public attention (Sneddon, 2000).

Due to global climate change and the influence of anthropogenic activities, potential climate venerability has become a most inclusive ecological problem that seriously limits the sustainability of livelihoods. Research on sustainable livelihoods has become particularly important to deepen the understanding of these potential risk factors. Despite the increasing number of publications on sustainable livelihoods research, not enough attention has been paid to this research area, and current research on sustainable livelihoods is mainly an analysis of the progress, content, and framework (methodology) of international sustainable livelihoods research, with most papers using mostly descriptive and statistical analysis in their methodology and research frameworks Most of the papers use descriptive analysis and statistical analysis, and the research framework is mainly based on the sustainable livelihoods approach developed by DFID. There are few research reviews on the attributes of sustainable livelihoods, overall synthesis, future projections, and even fewer studies on a systematic analysis of the current published literature. However, few studies have focused on SL research from the perspective of bibliographic or scientometrics analysis (Zhang and Chen, 2020). Therefore, it is very important to accurately grasp the research progress of sustainable livelihoods and analyze the attributes and characteristics of its knowledge evolution to advance the research in this field (Zhang et al., 2019).

As an important research method integrating mathematics, statistics, and bibliography, scientometrics is gradually adopted by various disciplines to describe, evaluate and predict the current status and trends of science and technology. Scientometrics are important quantitative tools for analyzing the progress of a research topic from a macro to a more micro perspective (macro perspective is based on the analysis of the whole research such as several papers, categories, re-research countries, institutions, journals, authors, while micro perspective is based on the interpretation of keywords, co-cited literature and focused literature), based on scientific peer-reviewed literature. The scientometric approach is the best way to identify research trends and key areas that can help researchers understand the evolutionary characteristics of research over time(Chen et al., 2010; Duan et al., 2020; Xie, H. et al., 2020; Xie, H.L. et al., 2020). Thus, it allows a systematic and comprehensive judgment of the development of a scientific research field. It also knowns as the science of science(Garfield, 1998; Zhang et al., 2009). In general, more literature or references obtained, the better the understanding of the research topic (Chen, 2017).

As research in the field of sustainable livelihoods continues to evolve and deepen, no discourse has been recorded on the evolution of the characteristics and hotspots of research changes in the field. Therefore, an econometric analysis of the literature in this field is necessary to clarify the knowledge base, the 
evolution of development, and future research hotspots in this field. To address the above knowledge gap.

We reviewed the progress status and determined the development trend of SLs research. Thus, we undertook a comprehensive scientometrics review of the development of SLs research and searched all documents relevant to global SLs research from 1900 to 2020. It observes the theoretical framework, methodological system, research areas, and research hotspots in this field, analyzes the development lineage and cooperation networks, explores the research frontier hotspots and development trends, and provides a scientific basis and reference for promoting international sustainable livelihood-related research. The study conducted using CiteSpace and R software (Biblioshiny package), and we produced a map of the scientific knowledge and visualized the overall development process of SLs research.

The results of these analysis (1) reveal the document pattern of SLs research at the global scale; (2) provide an accurate overview of the scientific evolutionary path for SLs research in the past 3 decades; (3) identify the current research hotspots; (4) predicate the future focus for SLs research.

\section{Data And Methods}

\subsection{Literature Search Strategy}

The ISI Web of Science core database was chosen as the data source, and the search subject was determined through expert consultation and a literature investigation. The search formula of the advanced method selected according to the SL research subject was TS =sustain* and TS=livelihood*. The database was taken from the retrieval period of 1900-2020, updated to 31 December 2020, and a refined selection of its articles. The document type was an article and documents reviewed were written in English. The exported document type was "full record and cited references", and the document format was "plain text". And each record contained the author, title, institute, keywords, journal, source document, abstract, and cited references.

\subsection{Scientometrics Analysis Method}

We used Microsoft Excel, R 3.6.2 software (Biblioshiny package), CiteSpace5.7.R2, and VOSviewer to mine, analyze, process, and visualize the literature data.

Biblioshiny was prepared by Dr. Massimo Aria of Federico II University of Naples, Italy, based on Bibliometrix's shiny software package using the $\mathrm{R}$ language. Biblioshiny allows relevant scientific measurement and visualization using an interactive web interface ${ }^{28}$. The research countries and institutions, influential journals, and important authors are systematically analyzed using online analysis.

CiteSpace was developed by Dr. Chaomei Chen, a professor at the School of Information Science and Technology at Drexel University in the United States, for dynamic complex network analysis and data 
visualization ${ }^{30,37}$. Like cameras, CiteSpace takes snapshots of specific fields based on time series and connects them to infer the changing process and development trends in the field ${ }^{38}$. The specific visualization has two main modes: the cluster view and the timeline graph. The timeline graph can cluster and display the evolution of knowledge (i.e. trends) in different periods using mutation detection ${ }^{30}$. The most powerful function of CiteSpace software is the cited references analysis of documents. By analyzing the clustering and key nodes in the co-cited network, the knowledge structure of research can be revealed ${ }^{36,39}$. This can help researchers identify research frontiers from the clustering of many literature knowledge bases and reveal the essential knowledge nodes contained in research frontiers. Clustering tags are usually extracted from the relevant citation literature using the Log-Likelihood Ratio (LLR) algorithm to represent the research frontier corresponding to a certain knowledge base. The unique feature of the timeline graph is that it can sketch the relationship between clusters and the historical span of documents in a cluster. Another function is citation burst analysis, and it refers to the number of citations to the article change dramatically over a short period. It is a useful method for exploring the development of research trends ${ }^{36}$. Using the mutation detection algorithm designed by Kleinberg ${ }^{28}$ to identify bursts that represent the frontier of research, explosive nodes can be extracted from large quantities of data ${ }^{28}$. The basic principle is tantamount to count the frequency of words in the titles, abstracts, keywords, and identifiers of literature records of papers in related fields, and to identify hot words in research frontiers based on the word frequency growth rate of these words.

VOSviewer is free software based on JAVA and developed in 2009 by van Eck and Waltman from the Centre for Science and Technology Studies (CWTS) of Leiden University in the Netherlands ${ }^{40}$. It is mainly oriented to document data and uses "network data", which allows relationship construction and visual analysis for the document knowledge unit. It can draw a scientific knowledge graph to show the relationship between the structure, evolution, and cooperation of the knowledge field ${ }^{40}$. Graphic forms include network visualization, overlay visualization, and item density visualization. In the item density visualization, the point with more neighboring items and higher weight of the neighboring items is closer to red. Oppositely, its color will come closer to blue ${ }^{40}$.

The keywords are utilized to condense and refine the core content of the research ideas in each study ${ }^{28}$. Keywords can uncover the research topic of the literature, and word frequency statistics of keywords can reflect the research status in the field. Each article has unique keywords. Analysis of keywords in a paper can reveal the paper's theme. However, some correlation must exist among the keywords in a paper, which can be expressed by the frequency of co-occurrence. It is generally believed that more that lexical pairs appear in the same document, the closer the relationship between the two topics. Co-occurrence analysis uses the common occurrence of lexical pairs or noun phrases in the literature set to determine the relationship between topics in the subject represented by the literature set. A co-word network composed of these word pairs can be constituted by counting the frequency of subject words appearing in the same document ${ }^{40}$. High-frequency keywords can be used as research hotspots and research topics in a period in the given field. Through the automatic algorithm of the VOSviewer software, these keywords were analyzed by co-occurrence, and clusters were formed that represent the current research 
area ${ }^{40}$. These clusters can indicate the most current lines of interest among related researchers. There is another function of this software by calculating the term's relevance and find the future direction of SLS research ${ }^{41}$. Analysis of terms' relevance is a helpful tool through the current and past development process of the research field, grasp the research hotspot, and provide a reference for the exploration of the starting direction of the research.

\section{Results And Discussion}

\subsection{Basic Data Information}

After classifying the retrieved document datasets and eliminating irrelevant documents, a total of 6441 documents and 265,759 references were compiled. It finds that the earliest document date of SL research was 1991. Over the past 30 years, an average of 6.7 documents on SL research was expected to be released per year, and the average number of citations per document was 21.26 . These results establish the rapid and high-quality development of SL research studies (Figure 1) with the Exponential model. These documents involved 19, 082authors, 939 were single-authored. They generated a total of 13, 979 keywords (Table 1).

Table 1. Basic information of datasets.

\begin{tabular}{cc}
\hline Type & Value/Number \\
\hline Timespan & $1991-2020$ \\
Documents & 6,441 \\
Average number of documents per year & 6.7 \\
Average number of citations per document & 21.26 \\
Average number of citations per year per document & 2.45 \\
References & 265,759 \\
Keywords plus (ID) & 8,245 \\
Author's keywords (DE) & 13,979 \\
Authors & 19,082 \\
Author appearances & 25,790 \\
Authors of single-authored documents & 939 \\
Authors of multi-authored documents & 18,143 \\
Single-authored documents & 1042 \\
Documents per author & 0.338 \\
Authors per document & 2.96 \\
Co-Authors per documents & 4 \\
Collaboration index & 3.36 \\
\hline
\end{tabular}

\subsubsection{Temporal Evolution of Documents}

Figure 1 is the number of annual documents related to SL research from 1990 to 2020 . This number increased from 9 in 1991 to 1004 in 2020, with a yearly annual growth rate of 331.17\%. Since 2006, the number of SL studies published annually exceeded 100. In 2017, the number of articles published will exceed 500. Research in the area of SL is gaining traction since 2016. Research on SL shows a typical exponential growth trend. 


\subsubsection{Web of Science Research Areas}

According to the Web of Science discipline distribution result of the category field, the areas of SL research will increase from 7 fields in 1991 to 142 in 2020. They were concentrated mainly in environmental science (2020), environmental studies (1539), green sustainable science technology (827), ecology (808), development studies (423), water resources (423). The main two research areas represented 3559 of the 6441 documents, making up approximately $55.25 \%$ of the total (Figure 2 ). This reveals that the SL studies have been primarily focused on environmental problems, although they also covered a wide range of other research areas, such as soil science, water resources, fisheries, plant sciences, and others. Therefore, disciplinary characteristics of SL research show a trend of interdisciplinary integration (Figure 2).

\subsubsection{Research Countries and Institutions}

Results show 135 countries to have engaged in SLs research. In terms of research countries, the Top five with the largest number of documents are the United States (1426), England (968), Australia (725), India (690), and China (564) (Figure 3). In addition to the number of documents, the centrality of domestic cooperation can also be used as one of the indicators to measure a country's research strength. Top five countries in terms of centrality are the United States of America (USA), Germany, China, Canada, and Australia. USA has cooperation with more than 20 countries, including China, Brazil, Australia, and South Africa, and China has cooperation with Germany, Canada, Australia, and Japan (Figure 5).

Figure 4 shows the percentage of single corresponding author and multiple corresponding authors in the top 15 countries in terms of the number of publications, where India has the highest percentage of single corresponding author with $63.5 \%$, followed by the US, UK, Australia, China, and South Africa with $36.89 \%$, $37.71 \%, 32.27 \%$, and $43.13 \%$, respectively. $46.27 \%, 43.13 \%$. The country with the highest percentage of non-corresponding author articles is Indonesia with $73 \%$, followed by France with $64.7 \%$. The countries with the ratio of the corresponding author to non-corresponding author articles close to 1:1 are Ethiopia (52.28\%), Sweden (52.31\%), Switzerland (55.61\%), Brazil (54.80\%), Italy (57.97), Belgium (52.48\%), and Bangladesh $(51.51 \%)$, where the percentage of non-corresponding author articles are in parentheses.

Results show 2341 institutions globally have engaged in SLs research. Five of the most-influential research institutions represented 833 articles (including cooperation achievements for each institution). The results show that the number of papers in one institution is significantly higher than that of other institutions, which indicate that the research documents of the five most-influential institutions are unbalanced. In terms of studies published from 1991 to 2020, the CGIAR ranked first with the largest number of papers (512), followed by the Wageningen University \& Research (216), Chinese Academy of Sciences (216) (Table 2).

Table 2. Top 10 productive institutions on SL research from 1991 to 2020. 


\begin{tabular}{ccc}
\hline Institution & TA & Loacation \\
\hline CGIAR & 512 & France \\
Wageningen University \& Research & 216 Netherlands \\
Chinese Academy of Sciences & 187 & China \\
Indian Council of Agricultural Research & 164 & India \\
University of California System & 137 & USA \\
Center for International Forestry Research 131 & Indonesia \\
University of London & 115 & UK \\
University of Queensland & 107 & Australia \\
CSIRO & 100 & Australia \\
University of British Columbia & 93 & Canada \\
University of Oxford & 91 & UK \\
State University System of Florida & 87 & USA \\
CIRAD & 86 & France \\
James Cook University & 83 & Australia \\
ICRAF & 80 & Kenya \\
\hline
\end{tabular}

Abbreviations: TA, total number of articles; CGIAR, Consortium of International Agricultural Research Center; CSIRO, Commonwealth Scientific and Industrial Research Organization; CIRAD, French Agricultural Research Centre for International Development; ICRAF, International Center for Research in Agroforestry.

\subsubsection{Influential Journals}

SLs studies have appeared in 1108 journals, and the average number of journals per year was reduced from 4 to 108 since 1991. Distribution of SL research documents within major journals was examined. The Top 30 (2.7\%) journals published 2207 (34.26\%) of the total number of documents. On the contrary, 527 journals (47.56\%) published only one paper, and 960 journals $(86.64 \%)$ published less than ten papers. As showed in Table 3, the Top three journals with the largest number of papers published are Sustainability (201), Land Use Policy (185), Ecology and Society (147). According to Bradford's Law, results reveal that the $S L$ research documents were highly dispersed with a large portion being published in ten journals as shown in Table 3 marked in *, that these journals are the core sources in SL research and play an essential role in understanding the progress of SL research. In addition to its prominent presence in specialized journals, SL research also makes a significant presence in internationally recognized general interest journals such as Nature (7), Science (4), and Proceedings of the National Academy of Sciences (31). This is quite uncommon in other sub-disciplinary studies.

Table 3. Top 20 journals ranked by the total local citation score (TLCS) in SLs research from 1991 to 2020. 


\begin{tabular}{|c|c|}
\hline Journal & TLCS NDH_iACPY_S IF \\
\hline World Development* & 405379305119953.86 \\
\hline Global Environmental Change-human and Policy Dimensions* & 583362200110.46 \\
\hline Proceedings of the National Academy of Sciences of the United States of America* & $2798 \quad 31219020079.41$ \\
\hline Science & $4 \quad 4 \quad 590200741.84$ \\
\hline Ecological Economics* & $2330 \quad 73273219973.89$ \\
\hline Ecology and Society* & 2308110252120064.14 \\
\hline Nature & $\begin{array}{lll}7 & 7 & 315200342.77\end{array}$ \\
\hline Journal of Environmental Management* & 210174242819984.17 \\
\hline Current Opinion in Environmental Sustainability* & $2096 \quad 46224620095.65$ \\
\hline Biodiversity and Conservation* & $2084 \quad 41235119963.14$ \\
\hline Marine Policy* & 207895212220013.22 \\
\hline Land Use Policy* & 2030127241619983.68 \\
\hline Progress in Human Geography & $5 \quad 538920006.76$ \\
\hline PLOS One* & 194172202720092.74 \\
\hline Conservation Biology* & 38205120035.40 \\
\hline Ecosystem Services* & 187749193820126.33 \\
\hline Sustainability* & $1850 \quad 30220 \quad 620112.57$ \\
\hline Forest Policy and Economics* & $1746 \quad 76212320023.13$ \\
\hline Agriculture Ecosystems \& Environment* & 170236204720004.24 \\
\hline Environmental Science \& Policy* & $1638 \quad 38194320084.76$ \\
\hline
\end{tabular}

Abbreviations: $X^{*}$, the journal is the core resource of SLs research; TLCS, the total local citation Score; ND, the number of documents; H_i, H index; PY_s, published year started; AC, average citation, impact factor (IF) in 2019.

Citation statistics have generally been used to evaluate the relative impact of an academic journal. These journals, such as World Development, Global Environmental Change-human and Policy Dimensions, Ecological Economics, and Ecology and Society, Journal of Environmental Management, Current Opinion in Environmental Sustainability also ranked in the top five in terms of citations in this limited data. These results indicate a substantial contribution of document quantity published in a journal to its TLCS value ${ }^{42}$. These results show that these journals not only have many documents but also have an important influence.

\subsubsection{Core Authors and Academic Community}

The results of the analysis of authors can identify those who are more energetic, productive or cited in SLs researches and the researcher networks' contribution to SLs studies. The results indicated that the Top five authors with the largest number of articles where Singh R.K. (28), Shackleton C.M. (26), Chirwa P.W. (22), Stringer L.C. (21), Milner-Guland E.J. (20) (Table 4). Dougill A.J. is ranked first, with an average number of citations of 54 per article, which is 16 times higher than that of the second-ranked author. Shackleton C.M., Stringer L.C., Dougill A.J. are the Top three authors in terms of the H index in this dataset (Table 4). According to Price's law, authors who published more than four papers on SLs research are identified as the core authors, of which there are 393. The Top 10 core authors are shown in Table 4.

These 6441 documents involve 19, 082 authors. A total of 939 independent authors published 100 studies. The remaining documents have 4.8 co-authors per document on average. The cooperation index is 3.17. Overall, each author contributed 0.338 documents on average, and each document had an average of 2.96 authors. This also points out that SLs research is typically a multi-author cooperative 
field (Figure 6). It should be pointed out that we do not distinguish between the order of authors in their list of names, the calculated document, and the citation; rather, we recorded a name if it was on the list of authors.

Table 4. Top 10 research authors' local impact ranked by total documents.

\begin{tabular}{|c|c|c|c|c|c|}
\hline Author & TDTLCS & SACH_i & YY_start & Institution & Country \\
\hline Singh R.K. & 28159 & 67 & 2008 & $\begin{array}{c}\text { College of Horticulture and Forestry, Central Agricultural University } \\
\text { ICAR-Central Soil Salinity Research Institute }\end{array}$ & India \\
\hline $\begin{array}{l}\text { Shackleton } \\
\text { C.M. }\end{array}$ & 26975 & 3815 & 2002 & Department of Environmental Science, Rhodes University & $\begin{array}{l}\text { South } \\
\text { Africa }\end{array}$ \\
\hline $\begin{array}{l}\text { Chirwa } \\
\text { P.W. }\end{array}$ & 22261 & 128 & 2008 & $\begin{array}{c}\text { Department of Plant and Soil Sciences, Faculty of Natural and } \\
\text { Agricultural Sciences, University of Pretoria }\end{array}$ & $\begin{array}{l}\text { South } \\
\text { Africa }\end{array}$ \\
\hline $\begin{array}{l}\text { Stringer } \\
\text { L.C. }\end{array}$ & 21505 & 2414 & 2007 & $\begin{array}{c}\text { Sustainability Research Institute, School of Earth and Environment, } \\
\text { University of Leeds }\end{array}$ & UK \\
\hline $\begin{array}{l}\text { Milner- } \\
\text { Guland E.J. }\end{array}$ & 20570 & 2912 & 2008 & $\begin{array}{c}\text { Interdisciplinary Centre for Conservation Science, Department of } \\
\text { Zoology, University of Oxford }\end{array}$ & UK \\
\hline Kumar S. & 18190 & 117 & 2012 & ICAR-Central Soil Salinity Research Institute & India \\
\hline Dougill A.J. & 16866 & 5412 & 2001 & School of Earth and Environment, University of Leeds & UK \\
\hline Azadi H. & 16154 & 107 & 2015 & $\begin{array}{c}\text { Hossein Azadi Department of Geography, Ghent University } \\
\text { Faculty of Environmental Sciences, Czech University of Life Sciences } \\
\text { Prague }\end{array}$ & $\begin{array}{r}\text { Belgium } \\
\text { Czech }\end{array}$ \\
\hline $\begin{array}{l}\text { Maikhuri } \\
\text { R.K. }\end{array}$ & 15350 & 2310 & 2000 & Department of Environmental Science, HNB Garhwal University & India \\
\hline $\begin{array}{l}\text { Hickey } \\
\text { G.M. }\end{array}$ & 15149 & 108 & 2012 & $\begin{array}{c}\text { Department of Natural Resource Sciences, Faculty of Agricultural } \\
\text { and Environmental Sciences, McGill University }\end{array}$ & Canada \\
\hline
\end{tabular}

\subsection{Analysis of the Keywords Co-occurrence}

In this study, a total of 22,224 keywords were detected in 6,441 papers on SLs research from 1991 to 2020. These keywords were analyzed by co-occurrence and six clusters were formed. These clusters are shown in Figure 7 based on the relationship between the link attribute weight of different keywords and the total link strength. Figure 7 shows the network of keywords that were selected from the total documents based on the co-occurrence method. Six clusters of the keywords and their links were grouped, and each group was identified with a different color. Figure 8 shows the group of pioneering keywords that has established the basis of the SLs studies ${ }^{41}$, such as livelihoods, deforestation, adaptation, impacts, resilience, governance. In addition, among the recent keywords related to this topic. The following are prominent: climate change, biodiversity, conservation, fisheries, land-use, ecosystem services, systems, adaptive capacity, community reliance. In this sense, the different periods in which sustainable livelihoods research has been conducted are a splendid collection, which can also validate the seven research themes identified in the research activities. Figure 8 visualizes the importance of key terms, based on when they were associated with this research. Thus, as the figure shows, older terms inform new ones.

Table 5 shows the six clusters that were examined. These were labeled using the keyword with the most occurrences and ranked by the percentage of keywords they included, as follows: cluster 1, red: 
livelihoods; cluster 2, green: conservation; cluster 3, deep blue: food security; cluster 4, yellow: management; cluster 5, purple: climate-change; cluster 6, light blue: ecosystem services. The weight of the link and the total link strength contributed by each representative keyword are included, and the 10 most important keywords are provided.

Table 5. Identified clusters of keywords on SLs research from 1991 to 2020.

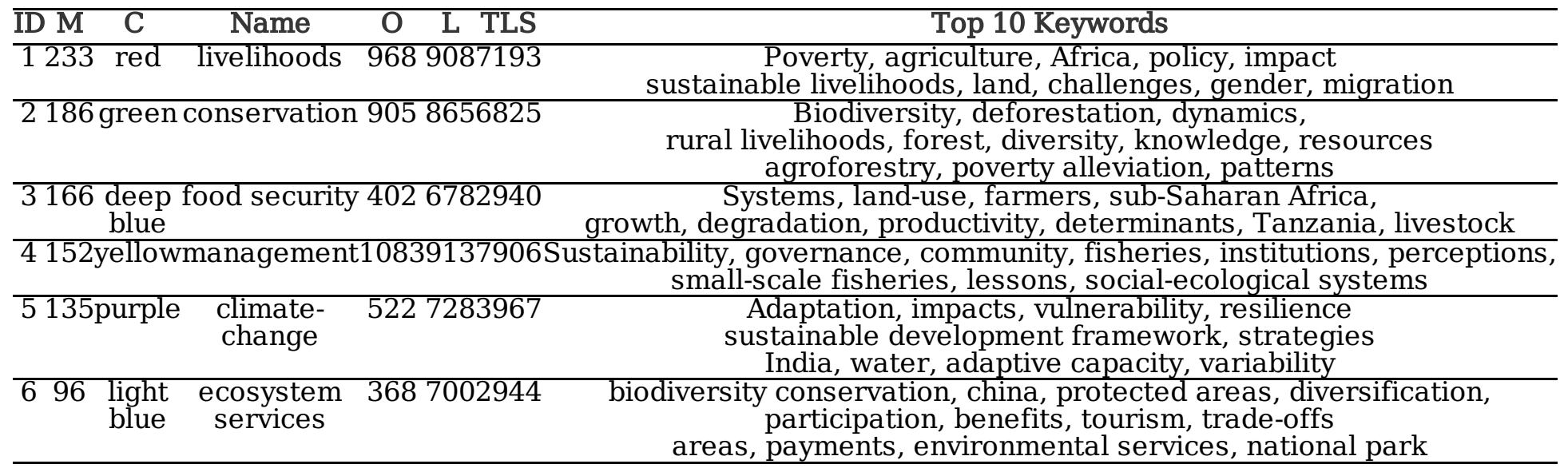

ID: cluster ID; M: cluster members; C: color in Figure 6; O: Occurrences; L: Weight Links; TLS: Weight Total Link Strength.

These key clusters are significant forms of visualization for many studies and are highly important for understanding the current research (Figure 6). Next, we introduce and further discuss each research area.

Livelihoods: This term focus on the interpretation and practical analysis of the sustainable livelihood framework. After entering the 21st century, the theory of sustainable livelihoods has not been particularly enriched but is based on the DFID framework-SLA 43,44, with different focus analysis, and using an evaluation indicator system to improve livelihoods in rural communities, such as policy, structure, livelihood capital, social equity, vulnerability environment, etc. in poverty eradication ${ }^{22,45,46}$, poverty eradication, etc. a lot of work has been carried out. These theoretical studies suggest effective and rational livelihood adaptation strategies. It is widely acknowledged that establishing an effective and innovative indicator system and monitoring program is critical to the success of global poverty reduction.

Conservation: The relationship between human livelihoods and the ecological environment has been one of the core scientific propositions of sustainable development today. In many developing countries, the livelihood choices of farmers, especially poor farmers, are often strongly dependent on the natural environment, and environmental resources provide them with various ecological services, making the exploitation of environmental resources an important source of income and means of livelihood for lowincome rural households. However, livelihood activities that are overly dependent on environmental resources can lead to environmental degradation, which can have important impacts on agriculture, forestry, livestock, and fisheries, as well as increase the impact of existing threats to food security and 
nutrition ${ }^{47-50}$, trapping farmers in a poverty-environment trap and even triggering environmental migration. Sustainable livelihoods depend on natural ecosystems and the rationalization of biological resource allocation, so balancing ecological and productive benefits is also an important element in achieving sustainable development. This includes conservation of biodiversity, application of indigenous knowledge, best management practices ${ }^{51,52}$, and optimal development models.

Food security: Food security (quality and quantity) is the most fundamental aspect of livelihoods, from land-use practices to productivity improvements and reproduction processes that directly determine the sustainability of local farmers' livelihoods ${ }^{53,54}$, when land degradation causes several problems $\llbracket$ decrease in the quantity and quality of crops, fur, etc. To ensure and maintain basic livelihoods, farmers will increase utilizing, leading to a new round of land degradation, and therefore food security is always a key concern for livelihoods. Due to severe poverty and widespread livelihood difficulties, regions such as Africa and India have become the focus of international research on sustainable livelihoods. They are important key regions for securing basic livelihoods and achieving "food security." 22,55-60.

Management: Management is a keyway of policy implementation, and governance is the last mile of management policy and an important influence on sustainable livelihoods. Different management models and governance mechanisms can directly affect the sustainability of livelihoods and the stability of social-ecological systems, so the impact of institutions on sustainable livelihoods is self-evident. Government policies at all levels and measures taken by international organizations and NGOs can directly or indirectly impact the livelihoods of the population. Ecological conservation policies are part of the hot spots in international sustainable livelihoods research in recent years. Global desertification studies have shown that government policies such as grazing bans and reforestation significantly impact residents' livelihoods. At the same time, the health of residents is also affected in the process of environmental management. At the macro level, relevant policies formulated by the government and sustainable livelihood measures adopted by non-governmental organizations have direct or indirect impacts on residents' livelihoods. In recent years, the impact of ecological compensation, reforestation, and grazing ban on sustainable livelihoods is one of the hot spots in global sustainable livelihoods research ${ }^{61-64}$.

Climate change: One of the most serious challenges facing humanity in the 21 st century, has a particularly significant impact on developmentally backward regions and ecologically fragile areas, where a large number of poor people are concentrated, and a large number of studies have shown that poor agricultural populations are more severely affected by climate change. Climate change has become an additional burden to rural poverty, not only limiting the ability of the poor to access a variety of livelihood capital, but also reducing their range of options for livelihood activities, posing serious challenges to livelihoods, resource degradation, food security, basic services, and social inequality in rural communities, and exacerbating the risk of livelihood vulnerability for farm households. As mentioned earlier, due to climate change and intensification of human activities, the instability, and vulnerability of ecosystems 
have increased to some extent, strengthening the frequency of livelihood risks, especially food security, water security, the emergence of uncertain climate, etc. will directly impact the livelihoods of farmers in vulnerable areas, because how to enhance livelihood capital and the ability to cope with risks and optimize livelihood strategies in a vulnerable environment has been a research component of sustainable livelihoods ${ }^{10,65-69}$.

Ecosystem services: The trade-off between livelihoods and ecology has been a topic of concern for researchers. The optimization of livelihoods without destroying ecological resources and ensuring resource sustainability is a shared concern. With the degradation of global ecosystems and the loss and reduction of useful ecosystem services, ecological compensation has received widespread attention from both developing and developed countries as an effective policy tool to address environmental issues. As a major provider of ecosystem services and a major participant in ecological compensation programs, the impact of ecological compensation on farmers' livelihoods is related to programming sustainability and social equity. At the same time, in promoting livelihood diversification, tourism development also plays a part in promoting livelihoods. It has been found that rural tourism, as an external force entering rural communities, inevitably has strong disturbances on the economic structure, social culture, resource allocation, and ecological environment of villages, thus bringing multiple impacts on farmers' livelihoods. However, further research is needed to determine whether it can fully replace or efficiently complement local livelihoods $61,70-72$.

\subsection{Analysis of the knowledge base of SLs research}

The temporal evolution of citing references in SLs research is shown in Figure 9. Utilizing the LLR algorithm, a total of 17 visual clusters were formed, with each representing a direction evolution according to their activeness in Table 7. The more active the current cluster is, the more it can represent the research frontier. In Figure 7, the color curves represent the co-citation links added in the corresponding color year. Larger nodes or nodes with red tree rings are particularly worth exploring because they are either highly referenced, have cited emergencies, or both. Based on their size from Table 6 , the clusters are numbered, with cluster \#0 being the most massive cluster placed at the top of the graph. The different clusters' timeline has different colors. As the timeline overview shows, the persistence of research content clusters is different. Some clusters last more than 15 years, while others have a relatively short life span. Some clusters have stayed active until 2019, the latest year for which references have been cited in this study. The clusters with the Top five activeness were selected for further analysis.

Table 6 Temporal properties of all clusters. 


\begin{tabular}{|c|c|c|c|c|c|c|c|c|c|}
\hline $\begin{array}{l}\text { Cluster } \\
\text { ID }\end{array}$ & Size & Silhouette & From & To & Duration & $\begin{array}{l}\text { Mean } \\
\text { (year) }\end{array}$ & Sustainability & Activeness & Label (LLR) \\
\hline 0 & 232 & 0.89 & 2011 & 2019 & 13 & 2015 & ++++ & Active & rural household \\
\hline 1 & 142 & 0.879 & 2007 & 2018 & 13 & 2012 & +++++ & Active & $\begin{array}{c}\text { agricultural } \\
\text { intensification }\end{array}$ \\
\hline 2 & 112 & 0.871 & 1998 & 2012 & 15 & 2014 & +++++ & Active & $\begin{array}{l}\text { conservation } \\
\text { intervention }\end{array}$ \\
\hline 3 & 112 & 0.871 & 2001 & 2016 & 16 & 2008 & +++ & Inactive & environmental service \\
\hline 4 & 104 & 0.904 & 2000 & 2015 & 16 & 2006 & +++ & Inactive & social research \\
\hline 5 & 91 & 0.906 & 1995 & 2012 & 18 & 2009 & +++ & Inactive & small-scale fisheries \\
\hline 6 & 88 & 0.935 & 1998 & 2010 & 13 & 2003 & +++ & Inactive & adaptive co-manager \\
\hline 7 & 77 & 0.973 & 1992 & 2004 & 13 & 1997 & +++ & Inactive & $\begin{array}{l}\text { ecological } \\
\text { economics }\end{array}$ \\
\hline 8 & 63 & 0.889 & 1995 & 2006 & 12 & 2012 & +++++ & Active & $\begin{array}{c}\text { livelihood } \\
\text { vulnerability }\end{array}$ \\
\hline 9 & 57 & 0.955 & 1996 & 2008 & 13 & 2005 & +++ & Inactive & south Africa \\
\hline 10 & 37 & 0.998 & 2000 & 2011 & 12 & 2001 & ++ & Inactive & less-favoured area \\
\hline 11 & 27 & 1 & 1995 & 2008 & 14 & 1998 & ++ & Inactive & market processes \\
\hline 17 & 10 & 0.995 & 2001 & 2014 & 12 & 2000 & + & Inactive & $\begin{array}{l}\text { ameliorative policy } \\
\text { option }\end{array}$ \\
\hline 18 & 9 & 1 & 2003 & 2010 & 8 & 1999 & + & Inactive & linking livelihood \\
\hline 21 & 7 & 1 & 1999 & 2005 & 7 & 1997 & + & Inactive & health ecology \\
\hline
\end{tabular}

Table 7. Top 10 cited references' main information ranked by times of the local citations. 


\begin{tabular}{|c|c|c|c|c|}
\hline Title & Sources & Author & Year L & G \\
\hline $\begin{array}{l}\text { Sustainable Rural } \\
\text { Livelihoods: A } \\
\text { Framework for } \\
\text { Analysis }\end{array}$ & $\begin{array}{l}\text { IDS working } \\
\text { papers }\end{array}$ & Scoones I. & 1998294 & $\begin{array}{l}\text { This paper outlines a framework for analysing } \\
\text { sustainable livelihoods }{ }^{11} \text {. }\end{array}$ \\
\hline $\begin{array}{l}\text { Governing the } \\
\text { Commons-The } \\
\text { evolution of institutions } \\
\text { for collective action }\end{array}$ & $\begin{array}{l}\text { ¿Governing the } \\
\text { Commons } \square\end{array}$ & Ostrom E. & 1990242 & $\begin{array}{l}\text { Understanding when collective action can be } \\
\qquad \text { effective }^{73}\end{array}$ \\
\hline $\begin{array}{l}\text { Rural Livelihood } \\
\text { Diversity in Developing } \\
\text { Countries: Evidence }\end{array}$ & DFID & Ellis F. & 2000237 & $\begin{array}{l}\text { This paper examines livelihood diversification as a } \\
\text { survival strategy of rural households in developing } \\
\text { countries }\end{array}$ \\
\hline $\begin{array}{l}\text { Capitals and } \\
\text { Capabilities: A } \\
\text { Framework for } \\
\text { Analyzing Peasant }\end{array}$ & $\begin{array}{l}\text { World } \\
\text { Development }\end{array}$ & Bebbington A & .1999213 & $\begin{array}{l}\text { This paper develops an analytical framework to } \\
\text { analyze the sustainability of rural liveli-hoods and } \\
\text { their impact on rural poverty, with a core } \\
\text { understanding in terms of livelihood asset }\end{array}$ \\
\hline $\begin{array}{c}\text { Livelihoods and } \\
\text { Poverty }\end{array}$ & & & & acquisition and transformation ${ }^{75}$. \\
\hline $\begin{array}{l}\text { Livelihoods } \\
\text { perspectives and rural } \\
\text { development }\end{array}$ & $\begin{array}{l}\text { Journal of } \\
\text { Peasant } \\
\text { Studies }\end{array}$ & Scoones I. & 2009204 & $\begin{array}{l}\text { This paper offers an historical review of key } \\
\text { moments in debates about rural livelihoods, } \\
\text { identifying the tensions, ambiguities and challenges } \\
\text { of such approaches }{ }^{2} \text {. }\end{array}$ \\
\hline $\begin{array}{l}\text { The Livelihoods } \\
\text { Approach and } \\
\text { Management of Small- } \\
\text { Scale Fisheries }\end{array}$ & Marine Policy & $\begin{array}{l}\text { Allison E.H. } \\
\text { and Ellis F. }\end{array}$ & 2001162 & $\begin{array}{l}\text { This paper argues that state-led management and } \\
\text { some newer community or territorial tenure } \\
\text { approaches, when premised on an in-complete } \\
\text { understanding of livelihoods, may result in } \\
\text { management directives that are in-consistent with } \\
\text { the social and economic goals of resource } \\
\text { conservation and management } \\
\text { c6. }\end{array}$ \\
\hline $\begin{array}{l}\text { A General Framework } \\
\text { for Analyzing } \\
\text { Sustainability of Social- } \\
\text { Ecological Systems }\end{array}$ & Science & Ostrom E. & 2009161 & $\begin{array}{c}\text { A common framework to organize research to } \\
\text { describe and explain complex social-ecological } \\
\text { systems (SES) }{ }^{77} \text {. }\end{array}$ \\
\hline $\begin{array}{l}\text { Sustainable livelihoods } \\
\text { guidance sheets }\end{array}$ & DFID & DFID & 1999156 & $\begin{array}{c}\text { Provides directional guidance for research on } \\
\text { sustainable livelihoods } 12\end{array}$ \\
\hline $\begin{array}{l}\text { Sustainable rural } \\
\text { livelihoods: Practical } \\
\text { concepts for the } 21 \text { st } \\
\text { century }\end{array}$ & $\begin{array}{l}\text { IDS discussion } \\
\text { paper }\end{array}$ & $\begin{array}{l}\text { Chambers R. } \\
\text { and Conway } \\
\text { R. }\end{array}$ & & $\begin{array}{c}\text { This is one of the earliest works on a clear concept } \\
\text { of "sustainable livelihoods" } 1 \text {. }\end{array}$ \\
\hline $\begin{array}{l}\text { Household Strategies } \\
\text { and Rural Livelihood } \\
\text { Diversification }\end{array}$ & $\begin{array}{l}\text { The Journal of } \\
\text { Development } \\
\text { Studies }\end{array}$ & Ellis F. & 1998138 & $\begin{array}{c}\text { This article reviews the recent literature on } \\
\text { diversification as a livelihood strategy of rural } \\
\text { households in developing countries }{ }^{78} \text {. }\end{array}$ \\
\hline
\end{tabular}

The most frequently cited paper in the co-cited literature is "Sustainable Rural Livelihoods: A Framework for Analysis" by Scoones I. (1998), who states that sustainable livelihoods should include the five dimensions of work-time creation, poverty reduction, well-being and capability, adaptability, vulnerability and resilience, and sustainability based on natural resources ${ }^{11}$. He combined the connotations of livelihoods (employment, poverty reduction) and sustainability to successfully explain the concept of sustainable livelihoods. Later he also pointed out that we need to think about how to effectively integrate macro and micro in a new livelihoods perspective, as some current livelihoods frameworks fail to link to the process of economic globalization, are too localized, and fail to link to the practical challenges of environmental sustainability and lack political economy analysis.

In terms of time series, the earliest knowledge network of sustainable livelihoods research can be traced back to Ostrom E's 1990 book "Governing the commons: the evolution of institutions for collective action", 
which focuses on the issue of small-scale public pond resources and proposes an institutional theory of autonomous organization and autonomous governance of public affairs based on a large number of empirical studies, is one of the earliest literature focusing on livelihoods issues. Another classic work is from Chambers R. and Conway R. (1992) Sustainable rural livelihoods: Practical concepts for the 21st century, a study that provided the direction for all future research on sustainable livelihoods ${ }^{1}$. This study provided the first unambiguous conceptual direction for all future research on sustainable livelihoods.

\subsection{Research Frontier Analysis}

\subsubsection{A burst study based on burst keywords analysis}

Burst keywords refer to words that suddenly emerge in a study and can reflect new fields or directions derived from the research. In CiteSpace, the Kleinberg mutation detection method is used to identify concepts in frontiers, Detecting and tracking subject bursts to stay current on trends in many fields has been recognized by the scientific community ${ }^{79}$. The top 30 SLs-related keywords were selected shown in Figure 10 through burst detection during 1991-2020. The top five burst keywords with the highest strength are poverty (14.39), India (11.17), redd (10.02), biodiversity (9.43), medicinal plant (9.12) during the research period. In terms of temporal persistence, the top five burst keywords are developing countries (1991-2011), Africa (1996-2005), environment (1997-2011), Asia (1997-2009), India (1998-2009), poverty (2001-2012). After the United Nations proposed sustainable household development goals 2030 in 2015, it caused a huge international reaction and directional impact on the study of sustainable livelihoods, such as social-ecological system, carbon sequestration, co-management, and other keywords emerged, which are still in the process of The keywords that emerged are project (2017-2020), river (2017-2020), sustainable development goals (2015-2020). Results of keyword burst detection are a valuable indicator in the process of combing the knowledge map and describing topics in the scientific literature ${ }^{80,81}$.

\subsubsection{Top 11 future research directions}

Table 8 presents the top 12 terms of SLs research based on the score relevance attribute calculated by VOSviewer (see section 2.2), which has allowed the identification of the 11 future lines of research with more importance.

Table 8 Main terms by score relevance.

\begin{tabular}{ccc}
\hline Rank & Term & Relevance Score \\
\hline 1 & Mass Tourism & 53.767 \\
2 & Solar Home System & 43.036 \\
3 & Artisanal and Small-Scale Mining & 37.166 \\
4 & Forest Quality & 35.633 \\
5 & Marine Protected Area & 34.325 \\
6 & Agricultural Sustainability & 33.705 \\
7 & Sustainable Rangeland Management & 31.899 \\
8 & Indigenous Knowledge & 29.095 \\
9 & Livelihood Alternatives & 28.144 \\
10 & Livelihood Vulnerability & 21.321 \\
11 & Livelihood Security & 20.340 \\
\hline
\end{tabular}


The following is a brief description of future research directions in SLs research.

Mass Tourismlln order to better promote the economic development of rural or undeveloped areas, mass tourism has become an important development component for poverty alleviation ${ }^{82}$, and there is literature on the potential dynamics of increasing tourist flows into poor countries and regions for development. The hypothesis of pro-poor tourism and its antecedents is that stronger linkages with the local economy can increase the proportion of tourism expenditures flowing to the poor. Thus, reducing poverty ${ }^{83-85}$. However, from the existing studies, it is found that most of the current studies focus on the static effect analysis of tourism impact on the livelihoods of farmers, neglecting the dynamic and process studies, and failing to reveal the process and mechanism of tourism impact on the livelihoods of farmers ${ }^{82}$.

Solar Home System $\square$ The Solar Home System (SHS) is an autonomous photovoltaic system that provides a cost-effective lighting and electrical supporting power supply mode for off-grid homes in remote areas ${ }^{86}$. In rural areas that are not related to the grid, SHS can be used to meet household energy needs and meet basic electricity needs. Battery charging electrification can improve people's lifestyles by providing power for lighting, radio, TV, cell phone charging, and other electricity. The availability and affordability of such energy services can also reduce the size of the rural-urban divide, thereby reducing migration ${ }^{23}$. This energy mix requires only a one-time investment or government-subsidized payment by the consumer, who overcomes the high-cost barrier. This model is not only applicable to households in the Qinghai-Tibet Plateau region of western China where people are scattered, but also to households with solar heating needs in Africa and Latin America, and India.

Artisanal and Small-Scale Mining: Artisanal mining was first described as a "poverty-driven activity" employing others who do not have jobs at the World Bank's International Roundtable on Artisanal Mining held in Washington, DC in May $1995^{87}$. In recent decades, this activity, characterized as "low-skilled, labor-intensive mineral extraction and processing," has grown exponentially in the developing world, attracting tens of millions of direct participants and creating hundreds of millions of income-generating opportunities in a range of upstream and downstream industries that have now taken root in subSaharan Africa, Asia, and Latin America in countless rural and peri-urban areas, playing an important role in sustaining the livelihoods of people in poor areas, but the livelihood issues and impacts of artisanal mining on rural communities remain much studied and debated in detail, and more research is needed to underpin the benefits of the trade-offs. 
Forest QualityロAs the world faces the challenges of climate change, food shortages, and improving the livelihoods of people, forests have a central role to play ${ }^{24}$. By 2050, the world will need to provide shelter, food, clothing, and livelihoods for an additional 2 billion people, according to a World Bank projection report. For centuries, forests have served as a natural safety net for communities in time of famine or other events affecting agriculture and food production; they provide the fruits, leaves, gum, nuts, timber, and wood for fuel. Forests support people and the animals they may depend on for trade or diet in times of crop failure. Many of the world's remaining forests are under increasing threat due to human activities and climate change ${ }^{88,89}$. Although the rate of deforestation has slowed in some areas, some 14.5 million hectares of the world's forests are still being lost each year. Therefore, the future focus on sustainable livelihood realization must be based on a greater emphasis on forest ecosystem conservation and capacity enhancement.

Marine Protected Area[Globally, MPAs have been based on protecting marine habitats and maintaining biodiversity, and while there have been some success, they have also disrupted the livelihoods of coastal village communities, caused severe economic shock, and triggered local conflicts ${ }^{90}$. The protection of MPAs contributes to the achievement of SDGs 14 and 15. The COVID-19 outbreak has increased the risk to MPAs as the Covid-19 pandemic has put coastal ports and harbors in lockdown for periods ranging from 2-3 months, suspending all maritime activities. Closure periods to stop the spread of coronavirus benefit marine biodiversity, but also have a significant negative impact on the livelihoods of coastal communities that depend on tourism and other marine activities. Without concerted efforts to promote new forms of livelihoods, it will be difficult to prevent populations from returning to the ocean, which poses a threat to marine biodiversity ${ }^{91}$. Therefore, it is more important than ever to promote mitigation solutions that maintain the fragile relationships that MPAs help build between local populations and the ocean.

Agricultural Sustainability: Through sustainable agriculture, communities are helped to develop forms of food production that are economically viable, ecologically sound, socially just, and supportive of rural culture that truly ensures the security of basic food production ${ }^{92}$. Through identified agricultural experiments, small-scale farmers in marginal, ecologically fragile areas learn low-cost resource conservation techniques to conserve biodiversity, regenerate soil fertility, manage water, and increase yields, while reducing their dependence on externally purchased inputs, reducing or lowering the cost of unnecessary inputs, and enhancing their livelihood capital. And increasingly, rural people are not dependent on agriculture alone for survival but have diverse livelihood strategies to ensure basic subsistence issues ${ }^{27}$. Food security, water security, and land security remains important concerns for future sustainable livelihood research. 
Sustainable Rangeland Management $[$ Grassland ecosystems are the largest type of ecosystems on the earth, accounting for about $40 \%$ of the earth's land surfaces ${ }^{93,94}$. They provide essential and unique ecosystem services such as raw materials, products, and other values for human beings ${ }^{95,96}$, and also sustain the livelihood of about 800 million people ${ }^{97}$. However, as grasslands experience increasing global climate change and high intensity of anthropogenic activities in the Anthropocene, potential grassland degradation has become a most global ecological problem which limits international economic development seriously, which constrains the development of livelihoods of the local inhabitants (they refers to pastoral areas' people in this paper). About $49.2 \%$ of the world's grassland has experienced different degrees of degradation, with nearly $5 \%$ of the grassland reaching severe degradation ${ }^{98}$. Therefore, achieving management of grassland ecosystems is not only important for maintaining sustainable livelihoods but also necessary for achieving sustainable development of grassland ecosystems ${ }^{99,100}$.

Indigenous Knowledge[Numerous scientific studies focus only on the effect of the policy itself, ignoring the importance of local people's indigenous knowledge ${ }^{101}$. This local knowledge is accumulated from local resource use and long-term management practices and is a blind spot for scholars, government policymakers, and NGOs. For example, the practical experience of land management in grassland shows that in the past, the design of pastoral policies was mostly based on "the assumption that herders are indifferent to the pasture they depend on for their livelihoods", but the emergence of the joint-family management model shows that herders have rich ecological knowledge, which allows them to develop strategies to reduce the risks posed by the natural environment. These strategies include transhumance and livestock breed diversification ${ }^{102}$. It is recommended that community-based adaptive grazing practices and local agroecological knowledge should be incorporated into the development of new grassland management policies ${ }^{103-106}$, and the construction of a case base of local indigenous knowledge should be increased to provide theoretical support for better scientific decision making.

Livelihood Alternatives[The original purpose of livelihoods research is to find the causes of poverty and provide multiple solutions, and therefore current research is mainly focused on poor and ecologically fragile areas ${ }^{107}$. However, due to the differences in natural conditions, resource endowments, economic development, history and culture, and religious beliefs in different regions, livelihoods have obvious regional characteristics, and the threats, challenges, and opportunities to build sustainable livelihoods vary from region to region ${ }^{108}$, and the livelihood characteristics and shocks faced by different groups in the same region are entirely different. Therefore, livelihood research should not be limited to poor areas, ecologically fragile areas, or farmers, but should be broadened to include a wide range of regions and research subjects ${ }^{109}$ and to conduct representative livelihood sustainability research on regional characteristics and typical groups in different regions. Meanwhile, more research is needed in the 
assessment of alternative ecology, the selection of alternative strategies, and the process and mechanism of alternative livelihoods.

Livelihood Vulnerability: Livelihood vulnerability is an important characteristic of poverty, and vulnerability refers to the degree to which exposure to shock, stresses, and hazards exhibits insufficient resistance, insecurity, and vulnerability to disaster ${ }^{1,22}$. Farmers' livelihood vulnerability studies have focused on three aspects of livelihood risk, adaptation to livelihood risk, and resilience to livelihood risk ${ }^{110}$. The increasing vulnerability and sensitivity of ecosystems of climate change and increased intensity of human activities are compounded by the impact of the novel coronavirus 2019 global pandemic ${ }^{111}$. Therefore, how to find the most suitable livelihood development model in an uncertain, changing and complex vulnerability environment will be the focus of future research.

Livelihood Security[Singh et al. ${ }^{21}$ proposed a sustainable livelihood security index by considering three aspects: ecological security, economic efficiency, and social equity, and conducted an empirical study in eastern India, proving that this approach can effectively balance the common concerns of economists, environmentalists, and egalitarians, and can provide a reference for achieving sustainable development ${ }^{25}$.

\section{Conclusions And Expectation}

We presented a comprehensive overview of the SLs research field from 1991 to 2020 using scientometrics analysis. In the past 30 years, SLs research has experienced exponential growth in the number of articles published, from nine articles in 1991 to 1004 articles in 2020. The first papers in the field of SLs were published in 1991, which given the clear concept of SLs, Over the past three years, the number of articles published has exceeded 500 documents each year, maybe due to the SDGs proposed since 2015. Results of the study showed that the United States, Australia, UK, China were the main research countries; the Consortium of International Agricultural Research Centers was the main research institution; influential journals included Word Development, World Development, Global Environmental Change-human and Policy Dimensions, Ecological Economics, and Ecology and Society, Journal of Environmental Management, Current Opinion in Environmental Sustainability, and Singh R.K., Shackleton C.M., Chirwa P.W., Stringer L.C., Milner-Guland E.J. were the core authors.

Through keyword analysis and keyword co-occurrence analysis, six main clusters were formed, representing the core of current research on sustainable livelihoods, namely: a grounded theory of sustainable livelihoods, the relationship between sustainable livelihoods and ecological resources, the relationship between sustainable livelihoods and climate change, trade-offs between sustainable 
livelihoods and well-being of ecosystem services, the impact of management policies on sustainable livelihoods, and sustainable livelihoods and livelihood security (food security).

The analysis of the co-citation of references as the basis for the development of sustainable livelihoods as a discipline showed that 14 major clusters were formed, and the clusters with more concentrated literature are: cluster\#0 rural household, cluster\#1 agricultural intensification, cluster\#2 cultural intensification, cluster\#3 conservation intervention, the clusters that are still active are: cluster\#0 rural household, cluster\#1 agricultural intensification, cluster\#2 cultural intensification, cluster\#8 livelihoods vulnerability. These active clusters are also an important basis for the development of sustainable livelihoods in the future. Based on the number of citations, the most cited co-cited literature is "Sustainable Rural Livelihoods: A Framework for Analysis" by Scoones I. (1998), and the earliest co-cited literature were found, Ostrom E's 1990 book "Governing the commons: the evolution of institutions for collective action", which laid the foundation for a clearer, deeper, more comprehensive and systematic understanding of sustainable livelihoods research. By analyzing the highly cited literature, new disciplinary foundations can be found for future disciplinary development. The article most important contribution is predicting 11 major directions for the future development of sustainable livelihoods using term relative scores, specifically: Mass Tourism, Solar Home System, Artisanal and Small-Scale Mining, Forest Quality, Marine Protected Area, Agricultural Sustainability, Sustainable Rangeland Management, Indigenous Knowledge, Livelihood Alternatives, Livelihood Vulnerability, Livelihood Security, The article gives specific explanations and descriptions for each direction. These works play an important disciplinary reference role for an in-depth understanding of the past and present of sustainable livelihoods research and an accurate grasp of future research directions, especially for scientists, governments, and international organizations to provide important guidance and reference for faster and better poverty eradication issues.

\section{Declarations}

Author Contributions: Conceptualization, T.L., Z.X., Y.W. and X.C.; Data curation, L.C.; Funding acquisition, Y.W. and X.C.; Investigation, J.P., X.S., A.X., Y.W., D.G., Y.H., X.C. and L.S.; Methodology, T.L., X.S., D.G. and X.C.; Supervision, Z.X.; Visualization, T.L. and L.C.; Writing-Original draft, T.L., Y.W. and Y.H.; WritingReview \& Editing, T.L., L.C., Z.X., L.T., Y.W., X.C. and X.S. All authors have read and agreed to the published version of the manuscript.

Funding: Please add: This research was funded by the CAS Strategic Priority Research Programme (XDA20050103) and the International Partnership Program of Chinese Academy of Sciences (121311KYSB20170004-04). T.L. received Griffith University Postgraduate Research Scholarships for his PhD project.

Acknowledgments: Thanks to Chen Chaomei for the computing support provided by CiteSpace software and $\mathrm{Li}$ Jie for answering questions related to his blog. Comments and suggestions from anonymous 
reviewers, the Academic Editor, and the Editor are greatly appreciated.

Conflicts of Interest: In this study, all authors declare there is no any conflict of interest.

\section{References}

1 Chambers, R. a. C., G.R. Sustainable Rural Livelihoods: Practical Concepts for the 21st Century. (1991).

2 Scoones, I. Livelihoods perspectives and rural development. The Journal of Peasant Studies 36, 171-196, doi:10.1080/03066150902820503 (2009).

3 Sen, A. Ingredients of Famine Analysis: Availability and Entitlements. The Quarterly Journal of Economics 96, 433-464, doi:10.2307/1882681 (1981).

4 Reutlinger, S. in Economic Development and Cultural Change Vol. 32 (ed Amartya Sen) 881-886 (University of Chicago Press, 1984).

5 Borowy, I. Defining Sustainable Development for Our Common Future: A History of the World Commission on Environment and Development (Brundtland Commission). (Taylor and Francis, 2013).

6 Martha G. Roberts, Y. G. a. The International Progress of Sustainable Development Research:A Comparison of Vulnerability Analysis and the Sustainable Livelihoods Approach. PROGRESS IN GEOGRAPHY 22, 11-21, doi:10.11820/dlkxjz.2003.01.002 (2003).

7 Editorial. Tracking progress on the SDGs. Nature Sustainability 1, 377-377, doi:10.1038/s41893018-0131-z (2018).

8 Peng, Y. et al. Global Dryland Ecosystem Programme (G-DEP): Africa consultative meeting report. Journal of Arid Land 12, 538-544, doi:10.1007/s40333-020-0056-z (2020).

9 Zhilin, L. I. et al. Functional Requirements of Systems for Visualization of Sustainable Development Goal (SDG) Indicators. Journal of Geovisualization and Spatial Analysis 4, doi:10.1007/s41651-019-0046-x (2020).

10 Hahn, M. B., Riederer, A. M. \& Foster, S. O. The Livelihood Vulnerability Index: A pragmatic approach to assessing risks from climate variability and change-A case study in Mozambique. Global Environmental Change 19, 74-88, doi:https://doi.org/10.1016/j.gloenvcha.2008.11.002 (2009).

11 Scoones, I. Sustainable Rural Livelihoods: A Framework for Analysis. IDS Working Paper No 72 (1998).

12 DFID. DFID sustainable livelihoods guidance sheets. 0 (1999). $<$ https://www.ennonline.net/dfidsustainableliving>. 
13 Morse, S., McNamara, N., ebrary, I. \& Springer, N. Sustainable livelihood approach: a critique of theory and practice. 2013 edn, Vol. 9789400762688 (Springer, 2013).

14 Serrat, O. in Knowledge Solutions Ch. Chapter 5, 21-26 (2017).

15 Knutsson, P. The Sustainable Livelihoods Approach: A Framework for Knowledge Integration Assessment. Human Ecology Review 13, 90-99 (2006).

16 Carney, D.

17 Zhao, Y. N., Fan, J., Liang, B. \& Zhang, L. Evaluation of Sustainable Livelihoods in the Context of Disaster Vulnerability: A Case Study of Shenzha County in Tibet, China. Sustainability 11, doi:10.3390/su11102874 (2019).

18 Zhao, Y., Chen, D. \& Fan, J. Sustainable development problems and countermeasures: A case study of the Qinghai-Tibet Plateau. Geography and Sustainability 1, 275-283, doi:10.1016/j.geosus.2020.11.002 (2020).

19 Siegel, P., Siegel, Siegel, P. B. \& World, B. Using an Asset-Based Approach to Identify Drivers of Sustainable Rural Growth and Poverty Reduction in Central America: A Conceptual Framework. (2005).

20 Smith, D. R., Gordon, A., Meadows, K. \& Zwick, K. Livelihood diversification in Uganda: patterns and determinants of change across two rural districts. Food Policy 26, 421-435, doi:https://doi.org/10.1016/S0306-9192(01)00012-4 (2001).

21 Singh, P. K. \& Hiremath, B. N. Sustainable livelihood security index in a developing country: A tool for development planning. Ecological Indicators 10, 442-451, doi:10.1016/j.ecolind.2009.07.015 (2010).

22 Ellis, F. \& Bahiigwa, G. Livelihoods and Rural Poverty Reduction in Uganda. World Development 31, 997-1013, doi:https://doi.org/10.1016/S0305-750X(03)00043-3 (2003).

23 Cherni, J. A. \& Hill, Y. Energy and policy providing for sustainable rural livelihoods in remote locations - The case of Cuba. Geoforum 40, 645-654, doi:https://doi.org/10.1016/j.geoforum.2009.04.001 (2009).

24 Soini, E. Land use change patterns and livelihood dynamics on the slopes of Mt. Kilimanjaro, Tanzania. Agricultural Systems 85, 306-323, doi:https://doi.org/10.1016/j.agsy.2005.06.013 (2005).

25 Ferrol-Schulte, D., Wolff, M., Ferse, S. \& Glaser, M. Sustainable Livelihoods Approach in tropical coastal and marine social-ecological systems: A review. Mar. Pol. 42, 253-258, doi:https://doi.org/10.1016/j.marpol.2013.03.007 (2013). 
26 You, H. \& Zhang, X. Sustainable livelihoods and rural sustainability in China: Ecologically secure, economically efficient or socially equitable? Resources, Conservation and Recycling 120, 1-13, doi:10.1016/j.resconrec.2016.12.010 (2017).

27 Sneddon, C. 'Sustainability' in ecological economics, ecology and livelihoods: A review. Progress in Human Geography - PROG HUM GEOGR 24, 521-549, doi:10.1191/030913200100189076 (2000).

28 Zhang, Y. \& Chen, Y. Research trends and areas of focus on the Chinese Loess Plateau: A bibliometric analysis during 1991-2018. Catena 194, doi:10.1016/j.catena.2020.104798 (2020).

29 Zhang, C., Fang, Y., Chen, X. \& Congshan, T. Bibliometric Analysis of Trends in Global Sustainable Livelihood Research. Sustainability 11, 1150 (2019).

30 Chen, C., Ibekwe-SanJuan, F. \& Hou, J. The structure and dynamics of cocitation clusters: A multiple-perspective cocitation analysis. Journal of the American Society for Information Science and Technology 61, 1386-1409, doi:10.1002/asi.21309 (2010).

31 Xie, H., Zhang, Y., Wu, Z. \& Lv, T. A Bibliometric Analysis on Land Degradation: Current Status, Development, and Future Directions. Land 9, doi:10.3390/land9010028 (2020).

32 Duan, P. L., Wang, Y. Q. \& Yin, P. Remote Sensing Applications in Monitoring of Protected Areas: A Bibliometric Analysis. Remote Sensing 12, 18, doi:10.3390/rs12050772 (2020).

33 Xie, H. L., Zhang, Y. W., Wu, Z. L. \& Lv, T. G. A Bibliometric Analysis on Land Degradation: Current Status, Development, and Future Directions. Land 9, doi:10.3390/land9010028 (2020).

34 Garfield, E. From citation indexes to informetrics: is the tail now wagging the dog? Libri, 67-80 (1998).

35 Zhang, W., Qian, W. \& Ho, Y.-S. A bibliometric analysis of research related to ocean circulation. Scientometrics 80, 305-316, doi:10.1007/s11192-007-1863-0 (2009).

36 Chen, C. Science Mapping: A Systematic Review of the Literature. Journal of Data and Information Science 2, 1-40, doi:10.1515/jdis-2017-0006 (2017).

37 Ouyang, W. et al. Heavy metal loss from agricultural watershed to aquatic system: A scientometrics review. Sci Total Environ 637-638, 208-220, doi:10.1016/j.scitotenv.2018.04.434 (2018).

38 Chen, C. Grand Challenges in Measuring and Characterizing Scholarly Impact. Frontiers in Research Metrics and Analytics 1, doi:10.3389/frma.2016.00004 (2016).

39 Chen, C. Hindsight, insight, and foresight: a multi-level structural variation approach to the study of a scientific field. Technology Analysis \& Strategic Management 25, 619-640, doi:10.1080/09537325.2013.801949 (2013). 

mapping. Scientometrics 84, 523-538, doi:10.1007/s11192-009-0146-3 (2010).

41 Abad-Segura, E., González-Zamar, M.-D., Vázquez-Cano, E. \& López-Meneses, E. Remote Sensing Applied in Forest Management to Optimize Ecosystem Services: Advances in Research. Forests 11, doi:10.3390/f11090969 (2020).

42 Xiang, H., Zhang, J. \& Zhu, Q. Worldwide earthworm research: a scientometric analysis, 20002015. Scientometrics 105, 1195-1207, doi:10.1007/s11192-015-1725-0 (2015).

43 Yang, L., Liu, M. C., Lun, F., Min, Q. W. \& Li, W. H. The impacts of farmers' livelihood capitals on planting decisions: A case study of Zhagana Agriculture-Forestry-Animal Husbandry Composite System. Land Use Policy 86, 208-217, doi:10.1016/j.landusepol.2019.04.030 (2019).

44 Liu, H. Y. et al. Livelihood Diversification of Farm Households and Its Impact on Cultivated Land Utilization in Agro-pastoral Ecologically-vulnerable Areas in the Northern China. Chinese Geographical Science 30, 279-293, doi:10.1007/s11769-020-1111-6 (2020).

45 Wang, F., Yang, D. G., Wang, C. J. \& Zhang, X. H. The Effect of Payments for Ecosystem Services Programs on the Relationship of Livelihood Capital and Livelihood Strategy among Rural Communities in Northwestern China. Sustainability 7, 9628-9648, doi:10.3390/su7079628 (2015).

46 Lyu, C. H. \& Xu, Z. Y. Crop production changes and the impact of Grain for Green program in the Loess Plateau of China. Journal of Arid Land 12, 18-28, doi:10.1007/s40333-020-0091-9 (2020).

47 Dickhoefer, U., Buerkert, A., Brinkmann, K. \& Schlecht, E. The role of pasture management for sustainable livestock production in semi-arid subtropical mountain regions. Journal of Arid Environments 74, 962-972, doi:10.1016/j.jaridenv.2009.12.006 (2010).

48 Nampanya, S. et al. Smallholder large ruminant health and production in Lao PDR: challenges and opportunities for improving domestic and regional beef supply. Animal Production Science 57, 10011006, doi:10.1071/an16023 (2017).

49 Wendiro, D., Wacoo, A. P. \& Wise, G. Identifying indigenous practices for cultivation of wild saprophytic mushrooms: responding to the need for sustainable utilization of natural resources. Journal of Ethnobiology and Ethnomedicine 15, doi:10.1186/s13002-019-0342-z (2019).

50 Estrada-Carmona, N., Attwood, S., Cole, S. M., Remans, R. \& DeClerck, F. A gendered ecosystem services approach to identify novel and locally-relevant strategies for jointly improving food security, nutrition, and conservation in the Barotse Floodplain. International Journal of Agricultural Sustainability 18, 351-375, doi:10.1080/14735903.2020.1787618 (2020).

51 Laflamme, M. A framework for sustainable rangeland livelihoods. The Rangeland journa/ 33, 339-351, doi:10.1071/RJ11023 (2011). 
52 Kemp, D. R. et al. Chinese degraded grasslands - pathways for sustainability. Rangeland J. 42 , 339-346, doi:10.1071/rj20033 (2020).

53 Schumann, K., Wittig, R., Thiombiano, A., Becker, U. \& Hahn, K. Impact of land-use type and barkand leaf-harvesting on population structure and fruit production of the baobab tree (Adansonia digitata L.) in a semi-arid savanna, West Africa. Forest Ecology and Management 260, 2035-2044, doi:10.1016/j.foreco.2010.09.009 (2010).

54 Schumann, K., Wittig, R., Thiombiano, A., Becker, U. \& Hahn, K. Impact of land-use type and harvesting on population structure of a non-timber forest product-providing tree in a semi-arid savanna, West Africa. Biological Conservation 144, 2369-2376, doi:10.1016/j.biocon.2011.06.018 (2011).

55 Scoones, I. WETLANDS IN DRYLANDS - KEY RESOURCES FOR AGRICULTURAL AND PASTORAL PRODUCTION IN AFRICA. Ambio 20, 366-371 (1991).

56 McCabe, J. T. Sustainability and livelihood diversification among the Maasai of northern Tanzania. Hum. Organ. 62, 100-111, doi:10.17730/humo.62.2.4rwrt1n3xptg29b8 (2003).

57 Fratkin, E. \& Mearns, R. Sustainability and pastoral livelihoods: Lessons from East African Maasai and Mongolia. Hum. Organ. 62, 112-122, doi:10.17730/humo.62.2.am1qpp36eqgxh3h1 (2003).

58 Ellis, F. \& Freeman, H. A. Rural Livelihoods and Poverty Reduction Strategies in Four African Countries. Journal of Development Studies 40, 1-30, doi:10.1080/00220380410001673175 (2004).

59 Mwacharo, J. M. \& Drucker, A. G. Production objectives and management strategies of livestock keepers in South-East Kenya: Implications for a breeding programme. Tropical Animal Health and Production 37, 635-652, doi:10.1007/s11250-005-4253-8 (2005).

60 Kangalawe, R. Y. M. \& Liwenga, E. T. Livelihoods in the wetlands of Kilombero Valley in Tanzania: Opportunities and challenges to integrated water resource management. Physics and Chemistry of the Earth 30, 968-975, doi:10.1016/j.pce.2005.08.044 (2005).

61 Ojima, D. S. et al. A climate change indicator framework for rangelands and pastures of the USA. Climatic Change, doi:10.1007/s10584-020-02915-y.

62 Qureshi, M. H. \& Kumar, S. Contributions of common lands to household economies in Haryana, India. Environmental Conservation 25, 342-353, doi:10.1017/s0376892998000423 (1998).

63 Bhattacharya, P. \& Hayat, S. F. Sustainable NTFP management for rural development: a case from Madhya Pradesh, India. International Forestry Review 6, 161-168, doi:10.1505/ifor.6.2.161.38399 (2004).

64 Dong, S. K. et al. Indigenous rangeland resource management in the mountainous areas of northern Nepal: a case study from the Rasuwa District. Rangeland J. 29, 149-160, doi:10.1071/rj07033 
(2007).

65 Howden, S. M. et al. Adapting agriculture to climate change. Proceedings of the National Academy of Sciences of the United States of America 104, 19691-19696, doi:10.1073/pnas.0701890104 (2007).

66 Kassam, K. A. Viewing Change Through the Prism of Indigenous Human Ecology: Findings from the Afghan and Tajik Pamirs. Hum. Ecol. 37, 677-690, doi:10.1007/s10745-009-9284-8 (2009).

67 Lkhagvadorj, D., Hauck, M., Dulamsuren, C. \& Tsogtbaatar, J. Pastoral nomadism in the foreststeppe of the Mongolian Altai under a changing economy and a warming climate. Journal of Arid Environments 88, 82-89, doi:10.1016/j.jaridenv.2012.07.019 (2013).

68 Wang, Y., Wang, J., Li, S. C. \& Qin, D. H. Vulnerability of the Tibetan Pastoral Systems to Climate and Global Change. Ecol. Soc. 19, 11, doi:10.5751/es-06803-190408 (2014).

69 Githumbi, E. N. et al. Pollen, People and Place: Multidisciplinary perspectives on Ecosystem Change at Amboseli, Kenya. Frontiers in Earth Science 5, doi:10.3389/feart.2017.00113 (2018).

70 Aryal, A. et al. Rangelands, Conflicts, and Society in the Upper Mustang Region, Nepal Status, Rights, and Traditional Rangeland Management Strategies. Mt. Res. Dev. 33, 11-18, doi:10.1659/mrdjournal-d-12-00055.1 (2013).

71 Oduor, A. M. O. Livelihood impacts and governance processes of community-based wildlife conservation in Maasai Mara ecosystem, Kenya. J. Environ. Manage. 260, doi:10.1016/j.jenvman.2020.110133 (2020).

72 Stabile, M. C. C. et al. Solving Brazil's land use puzzle: Increasing production and slowing Amazon deforestation. Land Use Policy 91, doi:10.1016/j.landusepol.2019.104362 (2020).

$73 \quad$ Matiaske, W. 515-518 (2015).

$74 \quad$ Ellis, F. Rural Livelihood Diversity in Developing Countries: Evidence and Policy Implications. ODI Natural Resources Perspectives 40 (1999).

75 Bebbington, A. Capitals and Capabilities: A Framework for Analyzing Peasant Viability, Rural Livelihoods and Poverty. World Development 27, 2021-2044, doi:https://doi.org/10.1016/S0305750X(99)00104-7 (1999).

76 Allison, E. \& Ellis, F. The Livelihoods Approach and Management of Small-Scale Fisheries. Mar. Pol. 25, 377-388, doi:10.1016/S0308-597X(01)00023-9 (2001).

77 Ostrom, E. A General Framework for Analyzing Sustainability of Social-Ecological Systems. Science 325, 419 - 422 (2009). 
78 Ellis, F. Household strategies and rural livelihood diversification. The Journal of Development Studies 35, 1-38, doi:10.1080/00220389808422553 (1998).

79 Wang, C. L., S.;Suo, X. 1688-1692 (IEEE).

$80 \mathrm{He}, \mathrm{D}$. \& Parker, D. S. in Proceedings of the 16th ACM SIGKDD international conference on Knowledge discovery and data mining 443-452 (Association for Computing Machinery, Washington, DC, USA, 2010).

$81 \quad$ (Association for Computing Machinery).

82 Biddulph, R. Limits to mass tourism's effects in rural peripheries. Annals of Tourism Research 50, 98-112, doi:https://doi.org/10.1016/j.annals.2014.11.011 (2015).

83 Ashley, C. \& Roe, D. Making Tourism Work for the Poor: Strategies and challenges in Southern Africa. Development Southern Africa 19, 61-82, doi:10.1080/03768350220123855 (2002).

84 Mitchell, J. \& Ashley, C. Tourism and Poverty Reduction: Pathways to Prosperity. Tourism and Poverty Reduction: Pathways to Prosperity, 1-157, doi:10.4324/9781849774635 (2009).

85 Cater, E. A. Tourism in the least developed countries. Annals of Tourism Research 14, 202-226, doi:https://doi.org/10.1016/0160-7383(87)90085-5 (1987).

86 Gustavsson, M. \& Ellegård, A. The impact of solar home systems on rural livelihoods.

Experiences from the Nyimba Energy Service Company in Zambia. Renewable Energy 29, 1059-1072, doi:https://doi.org/10.1016/j.renene.2003.11.011 (2004).

87 Baffour-Kyei, V., Mensah, A., Owusu, V. \& Horlu, G. S. A. K. Artisanal small-scale mining and livelihood assets in rural southern Ghana. Resources Policy 71, 101988, doi:https://doi.org/10.1016/j.resourpol.2021.101988 (2021).

88 Szabo, M. P. J., Olegario, M. M. M. \& Santos, A. L. Q. Tick fauna from two locations in the Brazilian savannah. Exp. Appl. Acarol. 43, 73-84, doi:10.1007/s10493-007-9096-8 (2007).

89 Kettle, C. J. Seeding ecological restoration of tropical forests: Priority setting under REDD+. Biological Conservation 154, 34-41, doi:10.1016/j.biocon.2012.03.016 (2012).

90 Pham, T. T. T. Tourism in marine protected areas: Can it be considered as an alternative livelihood for local communities? Mar. Pol. 115, 103891, doi:https://doi.org/10.1016/j.marpol.2020.103891 (2020).

91 Charles, A. et al. Fishing livelihoods as key to marine protected areas: insights from the World Parks Congress. Aquatic Conservation: Marine and Freshwater Ecosystems 26, 165-184, doi:https://doi.org/10.1002/aqc.2648 (2016). 
92 Makate, C., Makate, M. \& Mango, N. Sustainable agriculture practices and livelihoods in pro-poor smallholder farming systems in southern Africa. African journal of science, technology, innovation and development 9, 269-279, doi:10.1080/20421338.2017.1322350 (2017).

93 Milchunas, D. G., and W. K. Lauenroth. Quantitative effects of grazing on vegetation and soils over a global range of environments. Ecological Monographs 63, 327-366 (1993).

94 Cingolani, A. M., Noy-Meir, I. , and Diaz.S. Grazing effects on rangeland diversity: a synthesis of contemporary models. Ecological Applications 15, 757-773 (2005).

95 Bengtsson, J. et al. Grasslands-more important for ecosystem services than you might think. Ecosphere 10, e02582, doi:https://doi.org/10.1002/ecs2.2582 (2019).

96 Blair, J., Nippert, J. \& Briggs, J. in Ecology and the Environment Ch. Chapter 14, 389-423 (2014).

97 Archibold, O. W. Ecology of world vegetation. (Chapman \& Hall, 1995).

98 Gang, C. et al. Quantitative assessment of the contributions of climate change and human activities on global grassland degradation. Environmental Earth Sciences 72, 4273-4282, doi:10.1007/s12665-014-3322-6 (2014).

99 Shackleton, S. \& Campbell, B. Tenure, livelihoods and sustainable development - rangelands as systems for multiple land use and livelihood support. African journal of range \& forage science 20, 202209, doi:10.2989/10220110309485815 (2003).

100 LaFlamme, M. A framework for sustainable rangeland livelihoods. Rangeland J. 33, 339-351, doi:10.1071/rj11023 (2011).

$101 \mathrm{Xu}, \mathrm{J}$. Indigenous Knowledge for Sustainable Livelihoods and Resources Governance in MMSEA Region. (2003).

102 Soh, M. B. C. \& Omar, S. K. a. Small is Big: The Charms of Indigenous Knowledge for Sustainable Livelihood. Procedia, social and behavioral sciences 36, 602-610, doi:10.1016/j.sbspro.2012.03.066 (2012).

103 Fernández-Giménez, M. E., Batkhishig, B., Batbuyan, B. \& Ulambayar, T. Lessons from the Dzud: Community-Based Rangeland Management Increases the Adaptive Capacity of Mongolian Herders to Winter Disasters. World Development 68, 48-65, doi:10.1016/j.worlddev.2014.11.015 (2015).

104 Asante, W. A., Acheampong, E., Kyereh, E. \& Kyereh, B. Farmers' perspectives on climate change manifestations in smallholder cocoa farms and shifts in cropping systems in the forest-savannah transitional zone of Ghana. Land Use Policy 66, 374-381, doi:10.1016/j.landusepol.2017.05.010 (2017). 
105 Yang, Z. et al. Adaptive Strategies Adopted by Herders Against the Decollectivization of Rangeland in the Qinghai-Tibetan Plateau in China. Mt. Res. Dev. 39, D11-D20, doi:10.1659/mrd-journal-d19.00034.1 (2019).

106 Kiffner, C. et al. Community-based wildlife management area supports similar mammal species richness and densities compared to a national park. Ecol. Evol. 10, 480-492, doi:10.1002/ece3.5916 (2020).

107 Wright, J. et al. Reframing the concept of alternative livelihoods. Conservation biology : the journal of the Society for Conservation Biology 30, 7-13, doi:10.1111/cobi.12607 (2015).

108 Khedrigharibvand, $\mathrm{H}$. et al. Livelihood alternatives model for sustainable rangeland management: a review of multi-criteria decision-making techniques. Environment Development and Sustainability 21, 11-36, doi:10.1007/s10668-017-0035-5 (2019).

109 Gharibvand, H. K., Azadi, H. \& Witlox, F. Exploring appropriate livelihood alternatives for sustainable rangeland management. Rangeland J. 37, 345-356, doi:10.1071/rj15027 (2015).

110 Sujakhu, N. M. et al. Determinants of livelihood vulnerability in farming communities in two sites in the Asian Highlands. Water international 43, 165-182, doi:10.1080/02508060.2017.1416445 (2018).

111 Adu, D. T., Kuwornu, J. K. M., Anim-Somuah, H. \& Sasaki, N. Application of livelihood vulnerability index in assessing smallholder maize farming households' vulnerability to climate change in Brong-Ahafo region of Ghana. Kasetsart Journal of Social Sciences 39, 22-32, doi:https://doi.org/10.1016/j.kjss.2017.06.009 (2018).

\section{Figures}




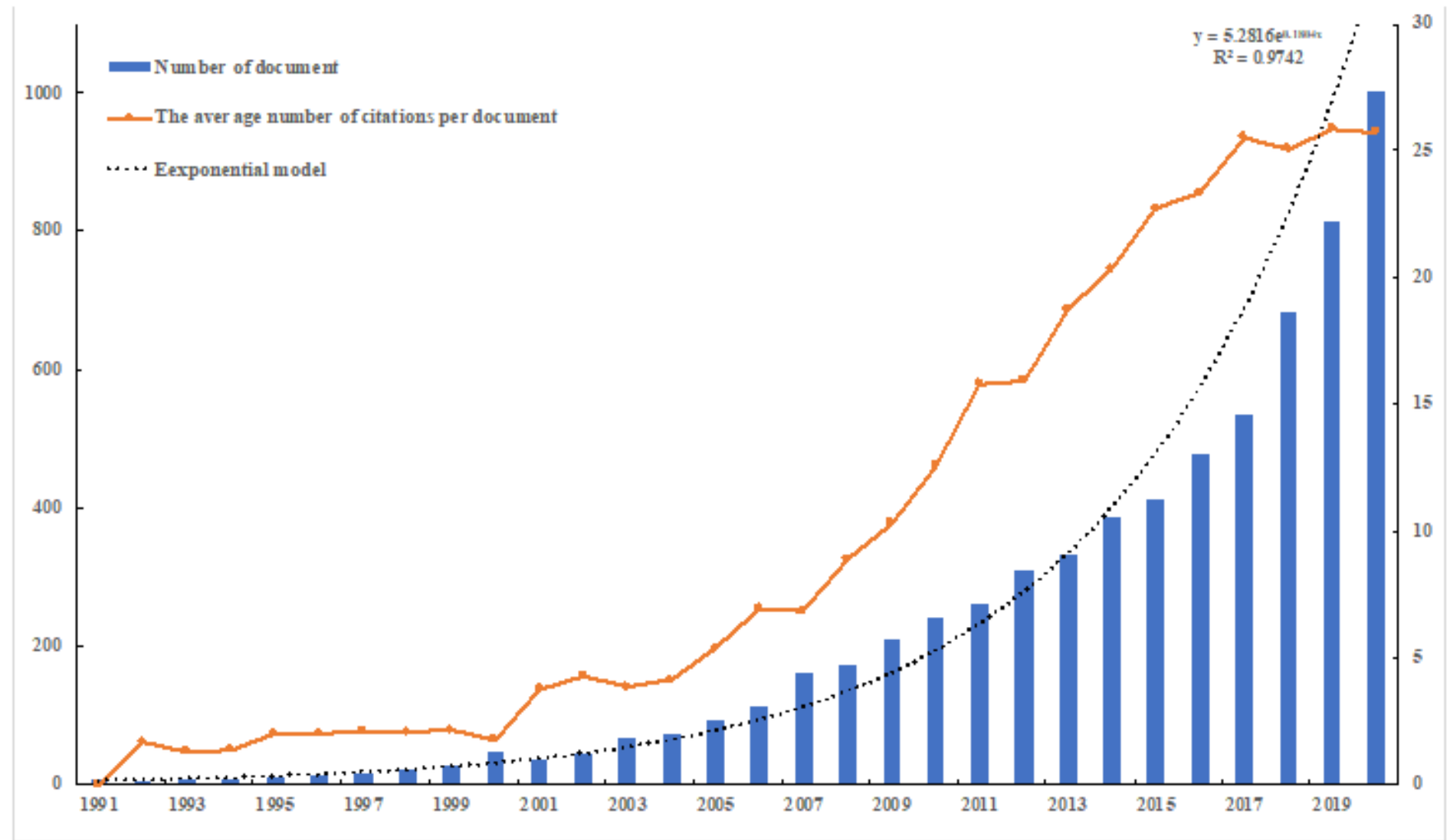

Figure 1

Temporal evolution of documents on sustainable livelihoods (SL) research from 1991 to 2020. 


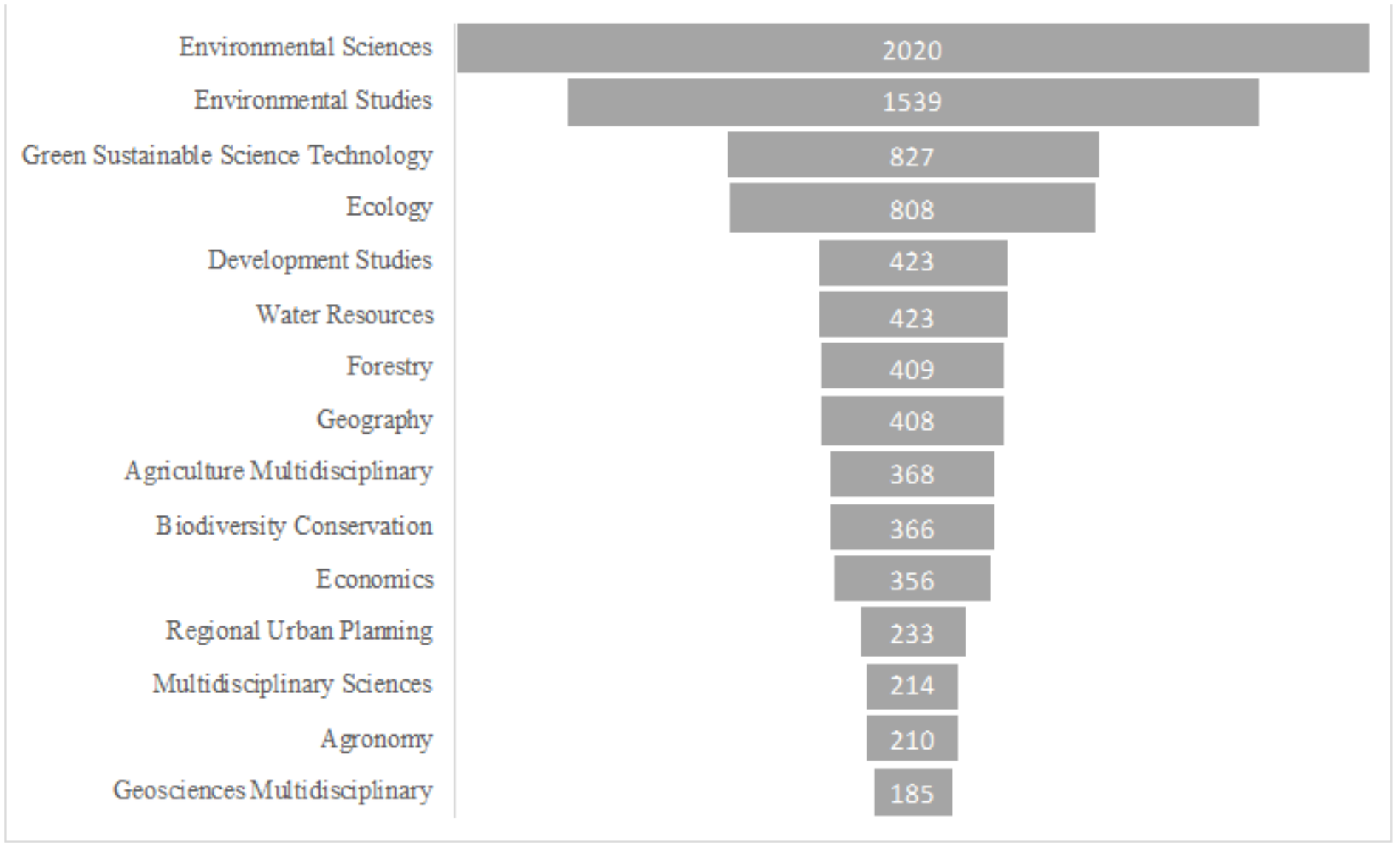

Figure 2

Top 15 main research fields in Web of Science on SL research studies from 1991 to 2020. 


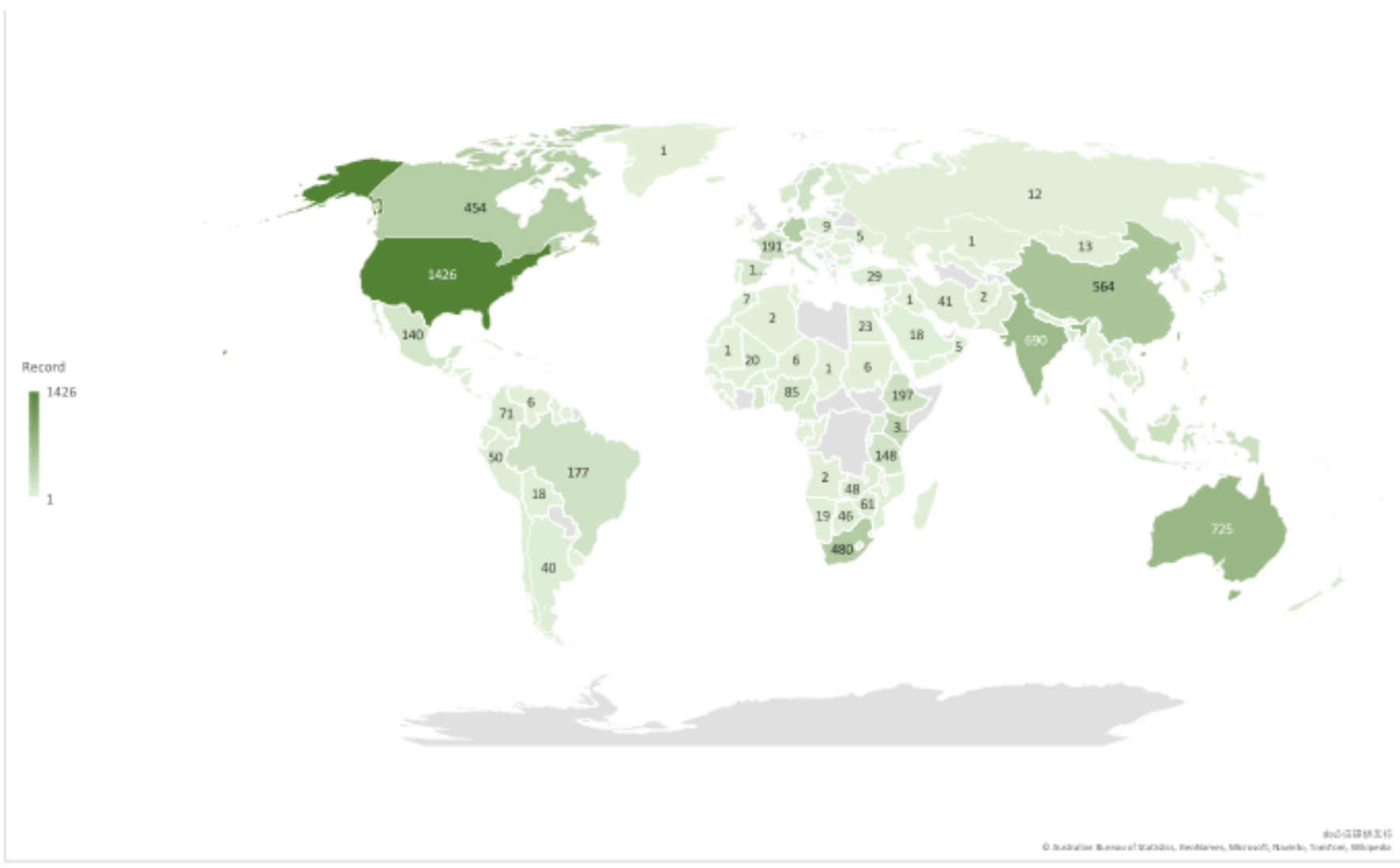

Figure 3

The number of documents per country in SLs research field. 


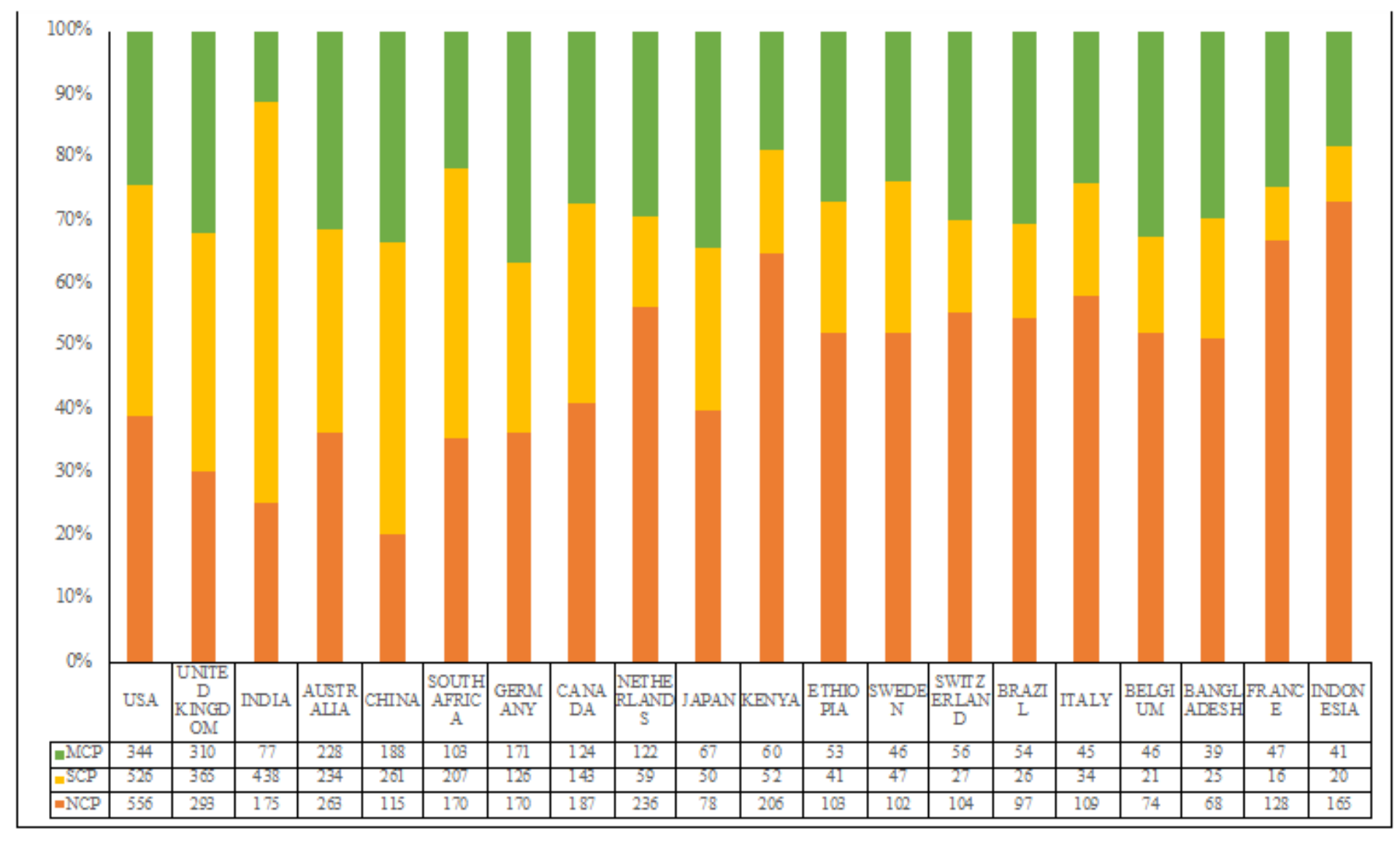

\section{Figure 4}

Percentiles of single-corresponding author publications (SCP)and multiple-author publications (MCP) and non-corresponding author publica-tions (NCP), based on the Top 15 countries in terms of total number of publications in SLs research field. 


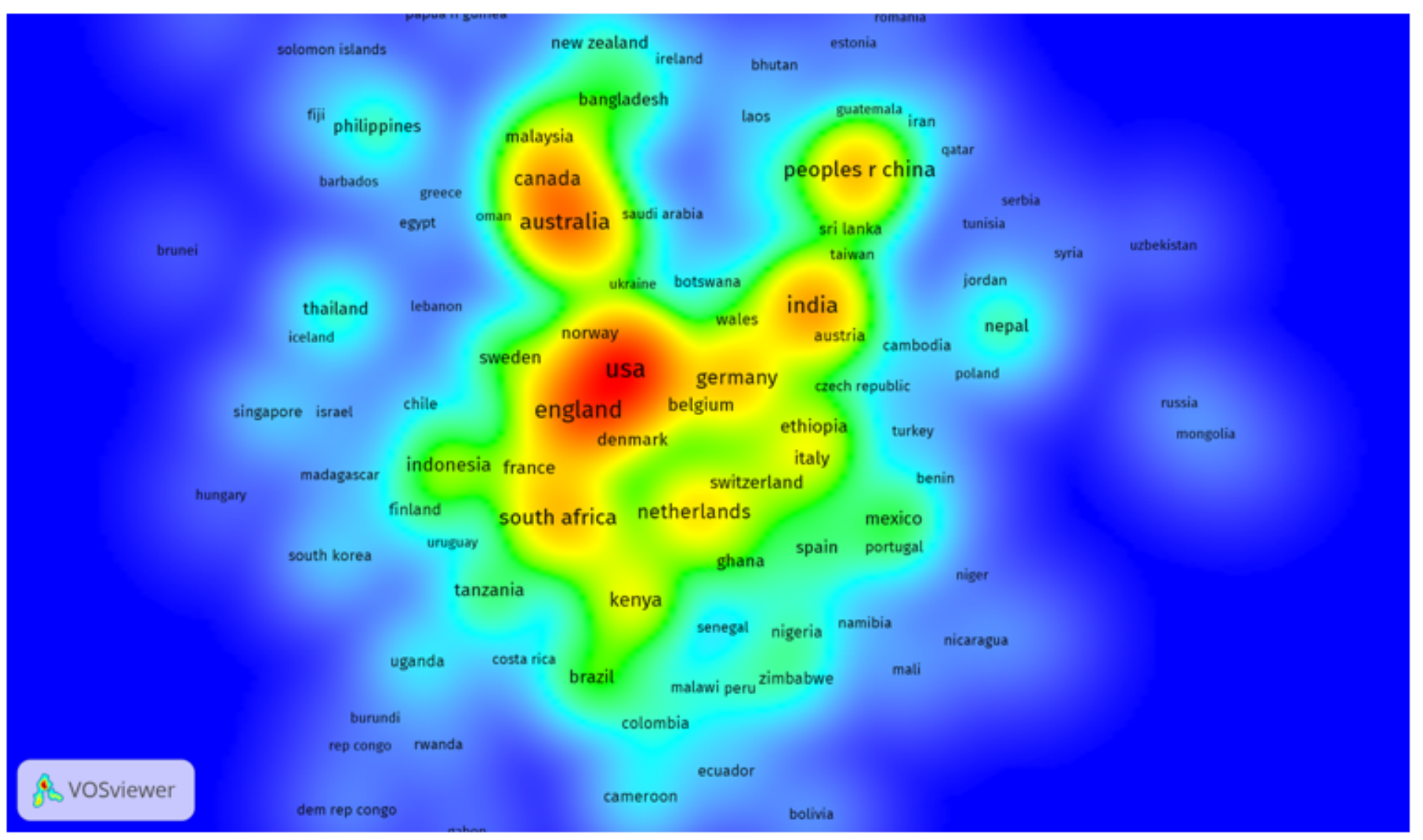

\section{Figure 5}

The cooperation density visualization between countries in SL research field.

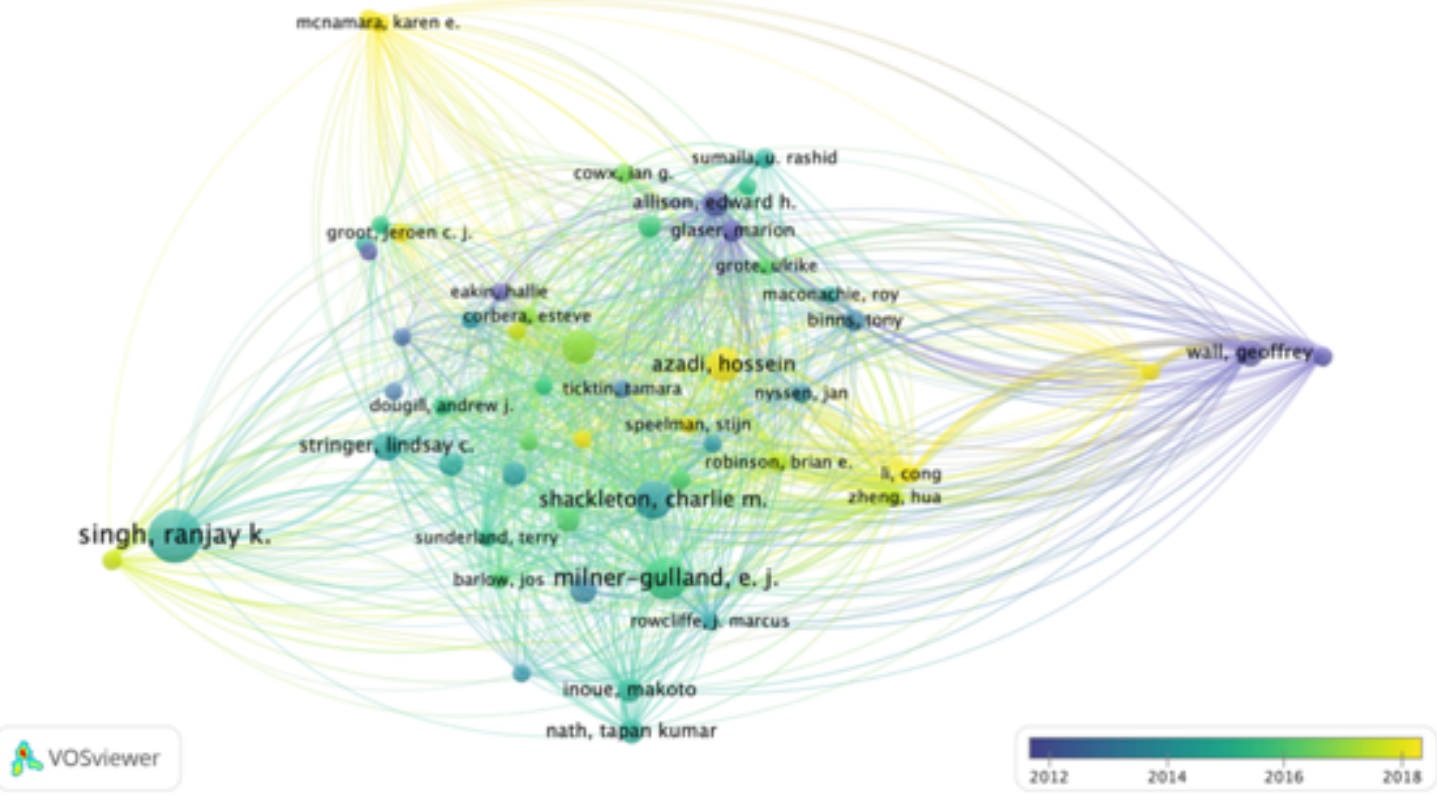

\section{Figure 6}

Evolution of authors' network based on the co-occurrence method on SLs research from 1991 to 2020. 
A. vosviewer

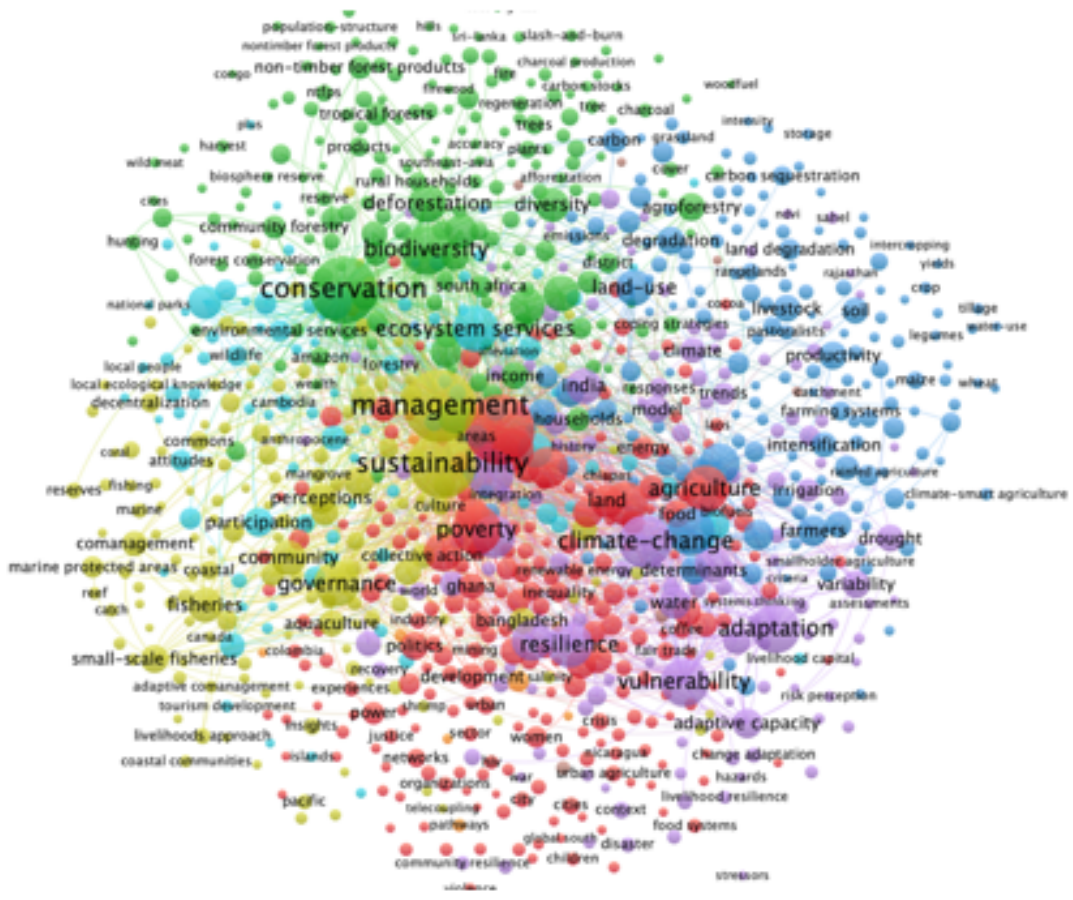

Figure 7

Network of keywords based on the co-occurrence method on SLs research from 1991 to 2020.

As vosviewer

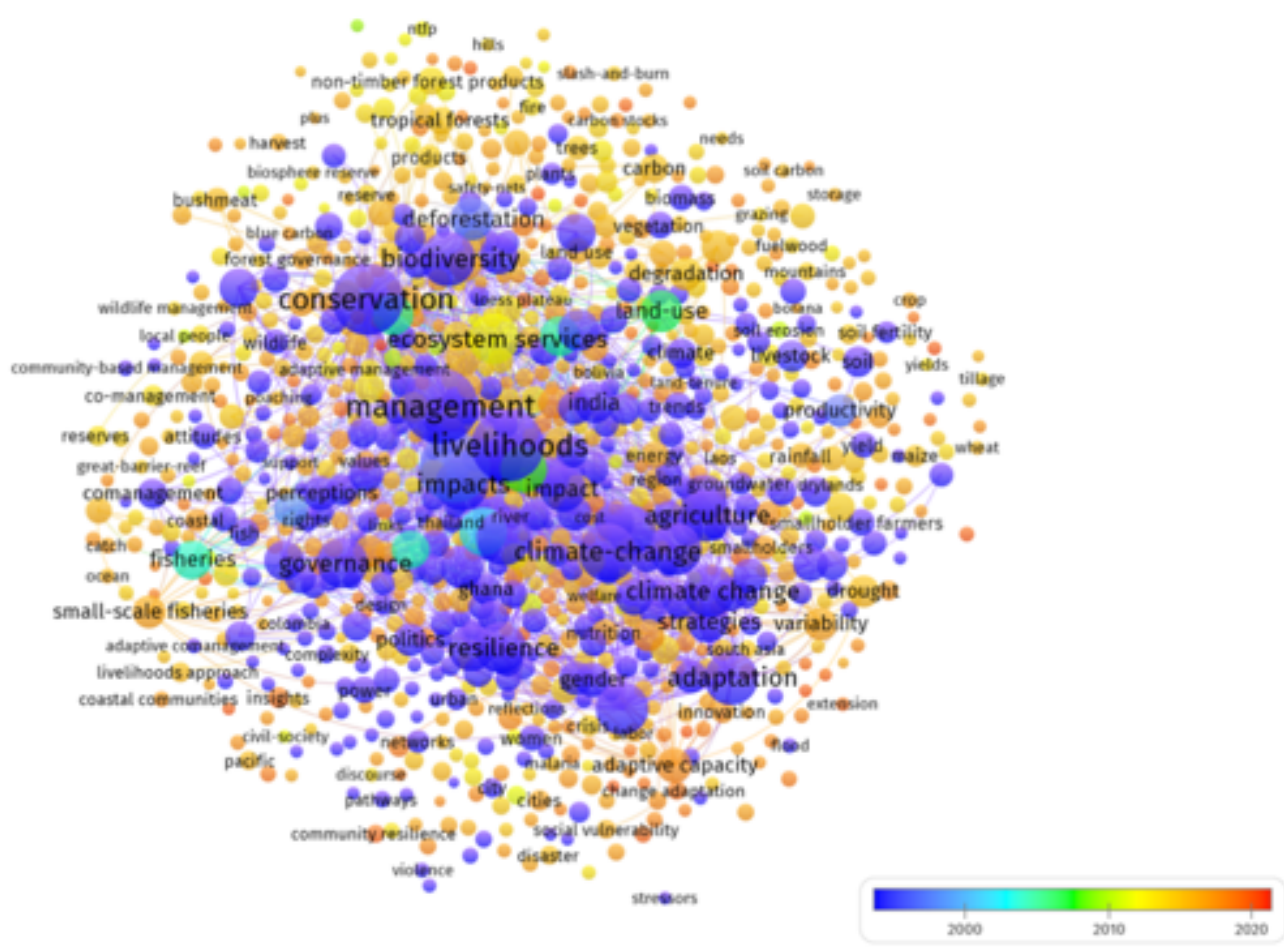

\section{Figure 8}

Evolution network of keywords based on the co-occurrence method on SLs research from 1991 to 2020. 


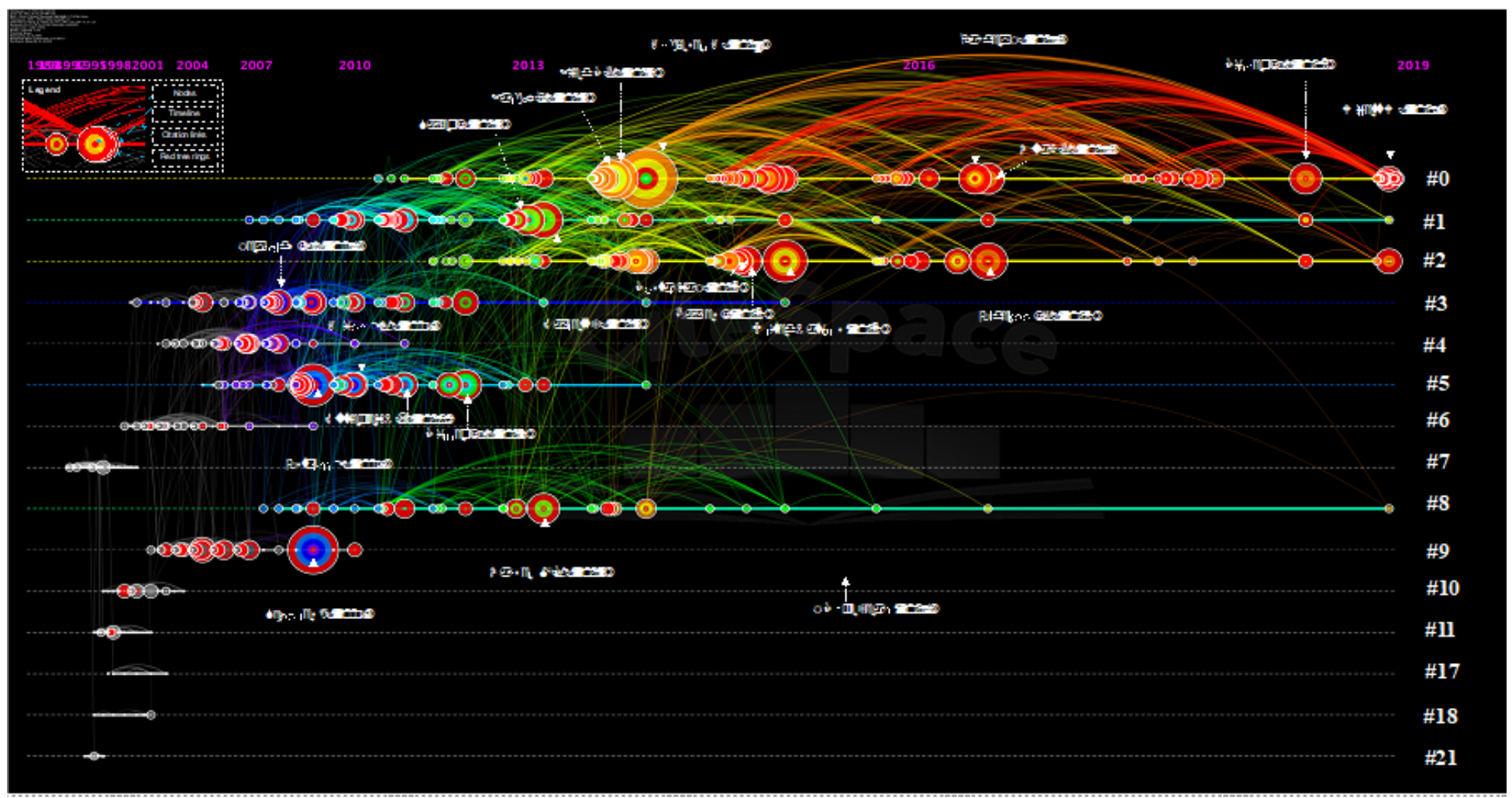

clusters' label: $\# 0$, nural household; \#1, agricultural intensification; \#2, conservation intervention; \#3, environmental service; \#4, social research; \#5, smatl-scale fisheries; \#6, adapive c0-mana ger; $\# 7$, ecological economics; \#8, livelihood vulnerability; \#9, s0uth Africa; \#10, less-favoured area; \#11, market processes; \#17, ame liorative policy option; \#18, linking live lihood; \#21, health ecology.

\section{Figure 9}

Visualization of clusters in terms of timeline view of the document co-citation analysis (DCA) in SLs research from 1980 to 2020. The horizontal axis represents the year, each node represents a popular cited reference, and the size of each node is proportional to its cited frequency, red tree rings means the burst. The line between each node represents the temporal evolution of the cited reference, and the line thickness represents the co-citation strength; these lines reflect the relationship between transfer and inheritance among cited references 30,36,39. 


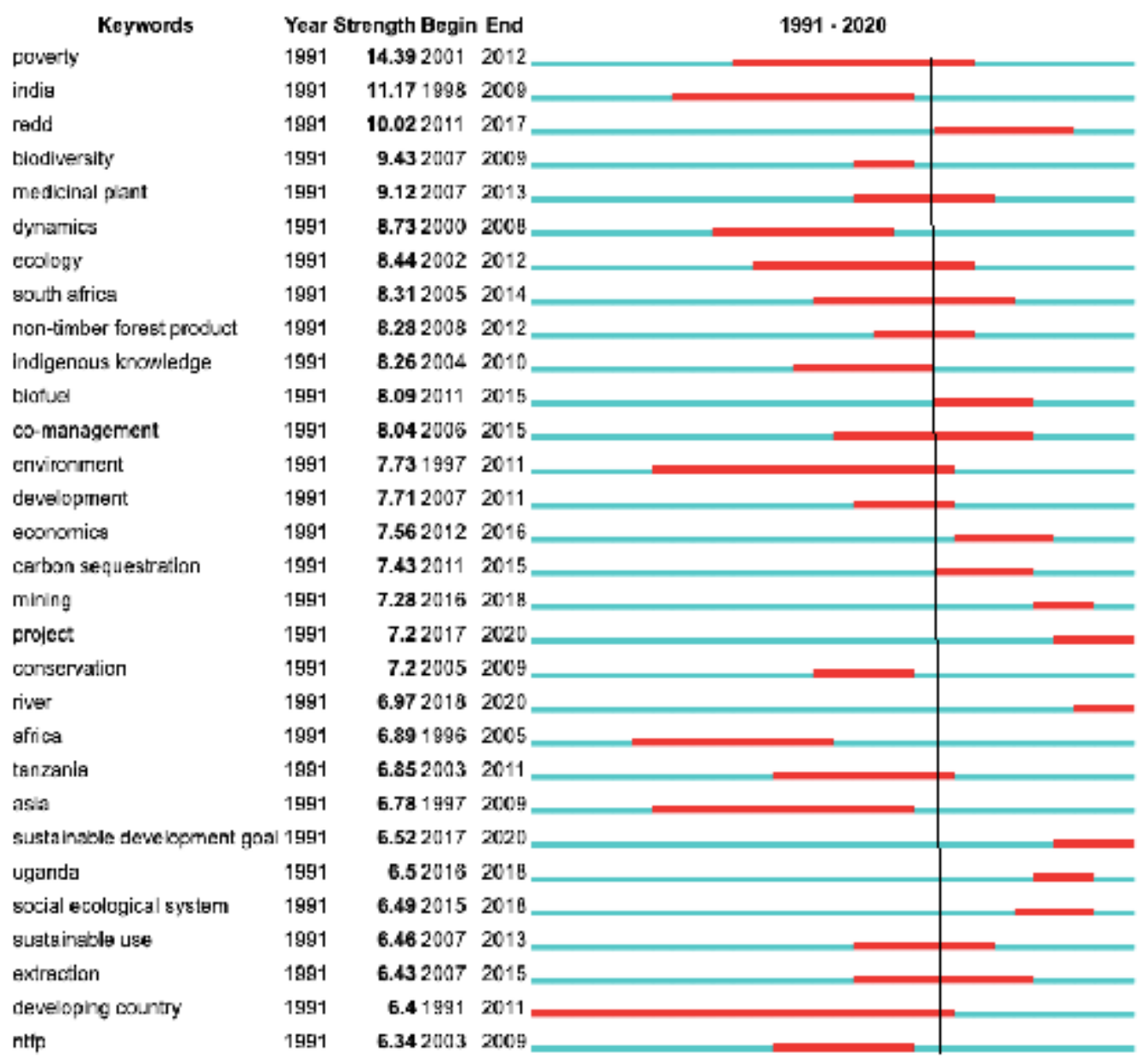

\section{Figure 10}

The burst detection results of the top 30 most frequent SLs-related keywords (The bold red lines represent the time periods of burst detection, with the total time span of the study being indicated by the bold blue lines, the black line is the dividing line from 2010). 